\title{
Reforming Indigenous welfare policy: Salutary lessons and future challenges for Australia from the US experience
}

\author{
A. Daly and D.E. Smith
}

No. 241/2002

ISSN 1036-1774

ISBN $073155616 \mathrm{X}$

Anne Daly is a Senior Lecturer in the Division of Management and Technology in the School of Economics and Marketing at the University of Canberra. Diane Smith is a Fellow at the Centre for Aboriginal Economic Policy Research, at the Australian National University. 



\section{Contents}

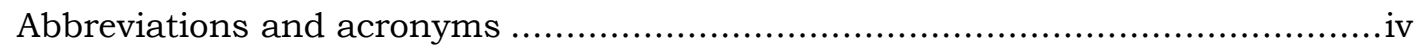

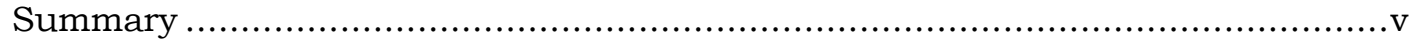

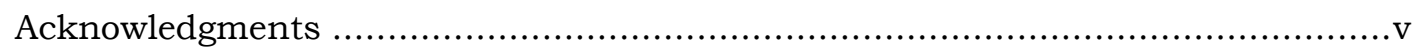

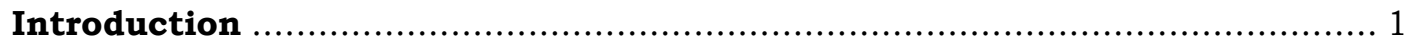

The Australian social security system and the direction of reform ............. 3

Welfare reform for Indigenous Australians ............................................. 5

The US social security system and the direction of reform ..................... 8

Welfare reform for Native Americans ................................................ 10

Key comparative characteristics: Native Americans and

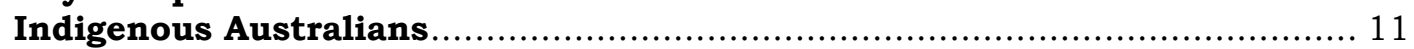

Salutary lessons and potential future challenges for Australia ................ 17

Work or education first? ............................................................. 17

Economic development: the paramount issue for welfare reform? ............... 19

The role of time limits ................................................................................ 20

Sustaining the exit from welfare to work …........................................ 21

The impact of welfare reform on families ............................................. 22

The policy focus: individuals, families, communities? ............................... 24

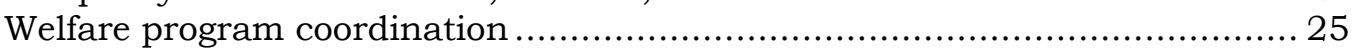

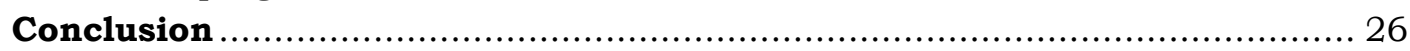

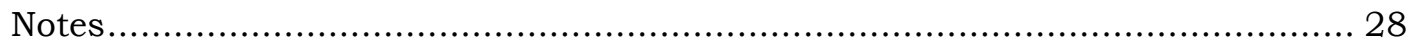

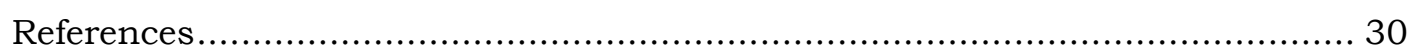

Figures

Fig. 1. ADFC/TANF and SPP/PPS recipients, USA and Australia, 1990-2000

\section{Tables}

Table 1. A comparison of Australian and US social security systems 4

Table 2. Selected characteristics of Native Americans (2000 Census) and Indigenous Australians (2001 Census)

Table 3. Census definitions of households and families in the USA (1990) and Australia (1991)

Table 4. Selected characteristics of Native Americans (1990 Census) and Indigenous Australians (1991 Census) 


\section{Abbreviations and acronyms}

$\begin{array}{ll}\text { AFDC } & \text { Aid to Families with Dependent Children (USA) } \\ \text { AGPS } & \text { Australian Government Publishing Service } \\ \text { ANU } & \text { The Australian National University } \\ \text { ATSIC } & \text { Aboriginal and Torres Strait Islander Commission } \\ \text { CA } & \text { Commonwealth of Australia } \\ \text { CAEPR } & \text { Centre for Aboriginal Economic Policy Research } \\ \text { CDEP } & \text { Community Development Employment Projects } \\ \text { CGC } & \text { Commonwealth Grants Commission } \\ \text { DFACS } & \text { Department of Family and Community Services } \\ \text { DHHS } & \text { Department of Health and Human Services (USA) } \\ \text { EITC } & \text { Earned Income Tax Credit (USA) } \\ \text { IUCN } & \text { International Union for the Conservation of Nature } \\ \text { JOBS } & \text { Job Opportunities and Basic Skills Training (USA) } \\ \text { NCAI } & \text { National Congress of American Indians } \\ \text { NEW } & \text { Native Employment Works (USA) } \\ \text { OECD } & \text { Organisation for Economic Cooperation and Development } \\ \text { PPS } & \text { Parenting Payment Single } \\ \text { PRWORA } & \text { Personal Responsibility and Work Opportunity Reconciliation Act } \\ \text { SPP } & \text { 1996 (USA) } \\ \text { SPRC } & \text { Sole Parent Pension (now subsumed under PPS) } \\ \text { TANF } & \text { Social Policy Research Centre } \\ \text { WtW } & \text { Welfare to Work (USA) } \\ & \end{array}$




\section{Summary}

Welfare reform in the USA began in the late 1980s and accelerated with the passage of the Welfare Reform Act in 1996. Welfare rolls have been cut dramatically. In contrast, welfare reform that incorporates the needs and entitlements of Indigenous Australians has only recently gained momentum and the welfare changes in Australia have been minor. Indigenous Australians are one of the groups disproportionately represented among welfare recipients and there has been intense debate about the best way of dealing with this problem. This paper examines the changes which have taken place in the USA, especially with respect to Native Americans, and considers the salutary lessons-both positive and negative-for welfare reform that focuses on Indigenous Australians. It summarises key relevant differences and similarities in the two social security systems and Indigenous population characteristics, and then identifes a set of important policy and economic conundrums that appear to have resonance in Australia. These include:

- the nexus between Indigenous welfare dependence and economic development;

- the roles of education and work in facilitating sustained exits from welfare;

- the role of time limits on eligibility for receipt of welfare and employment outcomes;

- the question of how to sustain post-welfare Indigenous employment;

- the issue of where the focus for policy and service delivery should lie-with individuals, families or their immediate communities; and

- the potential impacts of welfare reform on Indigenous families.

The paper concludes by considering the potential implications of policy transfer between the two countries, and draws out some key lessons and future challenges for reforming Indigenous welfare in Australia.

\section{Acknowledgments}

The issues considered in this paper, as well as its overall structure, have greatly benefited from comments made on a draft version by Jon Altman and Stephen Cornell. Each contributed his knowledge of and insights into, respectively, Indigenous Australian and Native American engagement with the welfare system. We also expanded our understanding of the intricacies of Native American welfare and economic development issues through a series of email discussions with Stephen Cornell. In 2002, Anne Daly presented a version of the paper at the Australian Economists' Conference in Adelaide, and also gave it as a seminar at the Department of Economics, University of Otago, Dunedin, New Zealand. She received useful feedback on both occasions. Our appreciation also goes to Frances Morphy who provided expert editorial input and assisted with layout; to Hilary Bek for proofreading; and to Wendy Forster for layout of the final version. 



\section{Introduction}

As countries across the world seek to reform their social security systems, the situation of indigenous populations within the changing welfare state is beginning to receive greater scrutiny. But as with other areas of social policy, there is often significant divergence between the demographic and socioeconomic characteristics of indigenous populations, and those of the wider populations within which they reside. Indigenous groups in many colonised 'settler' societies (such as Australia, the USA, Canada and New Zealand) generally evidence more youthful demographic profiles, higher rates of fertility and levels of adult mortality, poorer general health, lower levels of literacy and education, lower levels of income, and higher rates of unemployment than the national populations in their respective countries. Furthermore, indigenous populations often exhibit culturally-based institutions and systems of socioeconomic organisation that are distinctly different from those of the societies that encapsulate them.

While governments and policy makers emphasise the need for greater budgetary efficiency and lower welfare expenditure, they are also under increasing pressure to invest more in addressing the high levels of indigenous economic disadvantage and reliance on welfare transfers, and to do so by designing welfare policy and services that accord with indigenous institutions and priorities. In turn, many indigenous groups and their representative organisations are seeking greater selfdetermination over areas including welfare policy and services, and over the very process of welfare reform itself. Prominent Indigenous leaders in Australia are also challenging their own people to take greater responsibility for economic outcomes and for their high level of dependence on public transfers (see Ah Kit 2002; Pearson 2000). This complex web of factors makes welfare reform for indigenous populations a particularly challenging policy process.

Several reviews have highlighted the implications for Australia of the USA's experiment in welfare reform (see Burtless 2002; Ellwood 2002; Gray \& Stanton 2002; McClure 2000a; Perry 2002). However none have explored the more specific welfare initiatives that have been undertaken with Native American Indians, and the possible implications of those for Australian welfare reform focusing on Australian Aboriginal and Torres Strait Islander indigenous populations (hereafter 'Indigenous Australians'). This paper addresses that specific objective.

Welfare reform in the USA began in the late 1980s and accelerated with the passage of the Personal Responsibility and Work Opportunity Reconciliation Act (PRWORA) in 1996. As a consequence, the number of people listed on US welfare rolls overall have been cut dramatically, but relatively less so for Native American Indians (Brown 2001; Cornell et al. 2001). There is debate about the relative importance, in this outcome, of a buoyant economy and more stringent requirements for welfare support; and there is concern over the consequences for working-poor families. Nevertheless, there seems to be general agreement that the reforms in themselves have been significant in reducing reliance on welfare and increasing the transition from welfare to paid employment. In contrast, welfare 
reform in Australia has only recently gained momentum, and reported changes have been minor to date.

In both the USA and Australia, indigenous people are still disproportionately represented among welfare recipients and people in poverty. Both countries have welfare systems that have tended historically to treat indigenous welfare issues within the context of mainstream, national policy frameworks, albeit with adjustments by way of indigenous-specific components to service delivery and programs. ${ }^{1}$ Recently, however, a significant change, explicitly directed (in part) at Native Americans, has occurred in the USA, and has had significant effects on that group. In contrast, while there is an increasing sense of urgency in Australia about the need to make greater short-term investments to address Indigenous inter-generational welfare dependence and poverty, it is not clear how, or where, that investment would most productively be targeted. Nor is it clear what might constitute an enabling welfare policy framework to facilitate investment or reform. Since the USA, Australia and Britain already tend to adapt their national social security systems in the light of each others' experiences (see Dolowitz \& Marsh 2000; Pierson 2001; Walker \& Wiseman 2001), and in light of the intractable problems of entrenched indigenous economic marginalisation in both the USA and Australia, there may be salutary lessons-both positive and negative- to be learnt by Australia from the US experiment.

When exploring possible lessons and insights, it is important to keep in mind the similarities and differences between the US and Australian social security systems, and between the two indigenous populations. Accordingly, this paper proceeds by first examining the distinctive features of the Australian social security system and the direction of current welfare reform, and considers the situation of Indigenous Australians within that system. It then outlines the distinctive features of the US social security system, and describes an approach that has been taken specifically to address Native American needs within the process of national welfare reform. The paper further contextualises the comparison by describing some of the key socioeconomic characteristics that distinguish the two indigenous populations.

Against that backdrop, the advantages and disadvantages of the US approach to Native American welfare issues are then considered (both conceptually and empirically). In the process, a set of important policy and economic conundrums are identified that appear to have resonance and potential applicability as lessons for welfare reform for Indigenous Australians. These include:

- the nexus between Indigenous welfare dependence and economic development;

- the respective roles of education and work in facilitating sustained exits from welfare;

- the role of time limits on eligibility for receipt of welfare and employment outcomes; 
- the question of how to sustain post-welfare Indigenous employment;

- the issue of where the focus for policy and service delivery should lie-with individuals, families or their immediate communities; and

- the potential impacts of welfare reform on Indigenous families.

The paper concludes by considering the implications of the significant transfer of welfare policy thinking that already appears to be occurring between the two countries, albeit erratically through diffusion and adaptation rather than through any systematic process. In light of that very fluid process, and taking into account the key differences and similarities outlined in the paper, some salutary lessons and future challenges for the reform of the welfare system for Indigenous Australians are summarised.

\section{The Australian social security system and the direction of reform}

There are important differences between the social security systems operating in Australia and the USA. The key comparative features are set out in Table 1. While both countries have a federalised system of government, Australia has established a highly centralised, single national social security system. There is negligible devolution of welfare jurisdiction to Australian State governments, and none to Indigenous community or regional governing bodies, although some decentralisation of welfare service delivery and government office locations is occurring (Sanders 1999; Smith 2000). ${ }^{2}$ Since 1999, coordination of the social security system has been based on a division of policy and service delivery responsibilities between two separate Federal government departments. Centrelink is the service deliverer, and the Department of Family and Community Services (DFACS) is the policy formulation arm. The two are supposedly linked by a 'business agreement'. Other Federal departments have separate responsibility for education, training, and labour market program areas, while State and Territory governments differently administer a small range of child-protection, family support and domestic violence services.

In Australia, social security coverage is universal. It is regarded as a citizenship entitlement whereby an adequate level of baseline income should be provided by the state to people who can not support themselves (Kalisch 2000; Whiteford 2000). Income payments are not time-limited, although de facto time limits are applied to certain categories of recipients through activity tests and other eligibility criteria. Payments are made on a 'flat rate' system funded from general taxation, unrelated to previous earnings or individual contribution levels. Payments are targeted and made on categorical basis (e.g. aged, disability, carers, unemployed, sole parent), and complemented by an extensive system of additional payments for families with children. 
Table 1. A comparison of Australian and US social security systems

\begin{tabular}{|c|c|c|}
\hline $\begin{array}{l}\text { Feature of } \\
\text { system }\end{array}$ & Australia & USA \\
\hline $\begin{array}{l}\text { Scope and } \\
\text { structure }\end{array}$ & $\begin{array}{l}\text { Universal system, national } \\
\text { coverage; centralised system with } \\
\text { minimal State government } \\
\text { involvement. }\end{array}$ & $\begin{array}{l}\text { State-based system, Federal support } \\
\text { depends on States meeting minimum } \\
\text { standards; decentralised system with } \\
\text { maximum State government involvement. }\end{array}$ \\
\hline $\begin{array}{l}\text { Nature of } \\
\text { payments }\end{array}$ & $\begin{array}{l}\text { Social security payments means- } \\
\text { tested and made on a categorical } \\
\text { basis (e.g. old age pension, } \\
\text { unemployed, sole parent). Made } \\
\text { at a flat rate with no time limits, } \\
\text { just eligibility requirements. }\end{array}$ & $\begin{array}{l}\text { Unemployment benefits paid out of social } \\
\text { insurance. Social security payments } \\
\text { focused on families with children. Means } \\
\text { tested. Level of payments varies between } \\
\text { States. To be eligible for Federal } \\
\text { government funds, benefits are limited to } \\
\text { one spell of two years and a five-year } \\
\text { lifetime limit. }\end{array}$ \\
\hline $\begin{array}{l}\text { Policy and } \\
\text { statutory } \\
\text { framework }\end{array}$ & $\begin{array}{l}\text { Current welfare policy is } \\
\text { Australians Working Together } \\
\text { introduced in 2001. Main } \\
\text { statutory framework is Social } \\
\text { Security Act } 1999 .\end{array}$ & $\begin{array}{l}\text { Current policy at the Federal level operates } \\
\text { under Personal Responsibility and Work } \\
\text { Opportunities Reconciliation Act } 1996 \text { and } \\
\text { Balanced Budget Act 1997-Temporary } \\
\text { Assistance for Needy Families' (TANF) and } \\
\text { 'Welfare to Work' (WtW). }\end{array}$ \\
\hline Tax relief & $\begin{array}{l}\text { No system of tax credits for low } \\
\text { income earners. }\end{array}$ & $\begin{array}{l}\text { Earned Income Tax Credit (EITC)- } \\
\text { refundable tax credit for low-income } \\
\text { earners when annual tax is filed. }\end{array}$ \\
\hline Health cover & $\begin{array}{l}\text { Universal health coverage } \\
\text { through Medicare. Health care } \\
\text { card for low-income people. }\end{array}$ & $\begin{array}{l}\text { Medicaid for welfare recipients but no } \\
\text { universal system of health care cover for } \\
\text { low-income workers. }\end{array}$ \\
\hline $\begin{array}{l}\text { Additional } \\
\text { support }\end{array}$ & $\begin{array}{l}\text { Additional support for welfare } \\
\text { recipients, e.g. rent assistance } \\
\text { and public transport subsidies. }\end{array}$ & $\begin{array}{l}\text { Additional support for TANF recipients, e.g. } \\
\text { child care and transport. Food stamps } \\
\text { available to low-income recipients. }\end{array}$ \\
\hline $\begin{array}{l}\text { Indigenous } \\
\text { programs }\end{array}$ & $\begin{array}{l}\text { Indigenous-specific programs: } \\
\text { CDEP scheme, Indigenous } \\
\text { Employment Centres, Indigenous } \\
\text { Job Network providers. No } \\
\text { devolution, no enabling statutory } \\
\text { framework for Indigenous reform. }\end{array}$ & $\begin{array}{l}\text { Welfare jurisdictions devolved to } \\
\text { participating Native Americans via Tribal } \\
\text { TANF and Native Employment Works } \\
\text { (NEW). An enabling statutory framework for } \\
\text { Indigenous reform. }\end{array}$ \\
\hline
\end{tabular}

The Australian welfare system offers a wider range of benefits and pensions than those available in the USA. The most notable is the access to unemployment benefit without time limits if eligibility conditions (including activity testing) are fulfilled, as compared with the US system of unemployment insurance where it is necessary to be employed and contribute to an insurance fund before benefits can be received, for a maximum of six months.

Australian welfare reform has proceeded on a more limited scale than that now being undertaken in the USA. The Labor Federal government made a start with the introduction of a so-called 'Job Compact' under the Working Nation policy in 1994 (Keating 1994). Under the Job Compact, people who had been unemployed for 18 months or longer were guaranteed some work or training experience, but in return could lose their benefits if they refused to take up employment or training 
opportunities. Over the 1990s a series of reforms have also tightened eligibility for welfare pensions and benefits.

More recently, the Australian government has joined the international momentum towards welfare reform, motivated by a plethora of concerns: persistent unemployment and high levels of reliance on welfare payments, growing income inequality, the need to contain welfare expenditure, ${ }^{3}$ the lack of effective financial incentives for transferring to work, changes in the labour market and in work patterns, ${ }^{4}$ the fact of Australia's aging population, and changes in family formation (including the increasing number of sole parents (DFACS 2000). In the late 1990s the incumbent conservative Coalition government commissioned a major review of the Australian social security system. The final report, Participation Support for a More Equitable Society (McClure 2000b), provided a blueprint for national reform, advocating a radical overhaul of the Australian social security system.

As a consequence, Australian welfare policy currently suggests the problem of welfare dependency can be met by the creation of an 'active participation society' where individuals are expected to move 'beyond reliance on income support to self-sufficiency' by taking up paid work. The assumption is that employment is available and accessible to all welfare recipients. A major component of the Australian framework, emphasised in the most recent government policy statement, Australians Working Together (Commonwealth of Australia (CA) 2001) is the concept of a social contract based on a 'mutual obligation' existing between government and welfare recipients. ${ }^{5}$ Under mutual obligation, recipients are expected to undertake 'reasonable requirements' such as work experience, training or community work to prepare them for paid employment in return for their income support (DFACS 2001; CA 2001: 8). A financial penalty, or 'breaching', is applied for non-compliance. The recent formulation of this national welfare reform agenda is only now being translated into program action on the ground, and there is, as yet, no rigorous evaluation framework in place. It is thus too early to fully assess its success in meeting stated objectives, although there is some concern about its relevance and potential impacts upon Indigenous Australians (Smith 2000).

\section{Welfare reform for Indigenous Australians}

The changing position of Indigenous Australians in relation to the Australian social security system has been characterised as exclusion up to the 1960s, followed by a rapid transition to inclusion and a steady movement to greater levels of reliance on the welfare system over the last 30 years (Altman \& Sanders 1995). Until the late 1970s, welfare payments to many 'eligible' Indigenous people, especially those living on reserve lands, continued to be made to third parties (usually government and church officials) on their behalf. By the early 1980s, all Indigenous Australians were treated as eligible for all social security payments, including unemployment benefits, although access to services and payments has been erratic. 
In 1974, the Australian Commission of Inquiry into Poverty reported an Indigenous poverty rate of 48 per cent (Brown, Hirschfeld \& Smith 1974; Henderson 1975). In the mid 1990s it was estimated that 55 per cent of Indigenous respondents to the first National Aboriginal and Torres Strait Islander Survey received some form of social security payment as their main source of income. Among the wider Australian population, in contrast, 13 per cent of households received their primary income from social security payments (Altman \& Hunter 1998; Daly 1999). While the relative state of Indigenous welfare dependence has not changed significantly over the last 20 years, there has been an absolute increase in the number of Indigenous people reliant on income support payments. The factors underlying that increase include a 33 per cent increase in the Indigenous population between 1991 and 1996, a rapid increase in the Indigenous working-age population, a youthful Indigenous demographic profile with high dependency ratios, and the continued failure of employment opportunities to keep pace with Indigenous population growth.

The process and outcomes of Indigenous incorporation into the social security system have been hotly debated from the 1970s onwards. The debilitating socioeconomic and cultural impacts of the high rate of Indigenous welfare dependence have been extensively commented on (Pearson 2000; Smith 2000, $2001 \mathrm{a}, 2001 \mathrm{~b})$. But on the other hand, welfare payments have also provided Indigenous people with a valuable base-level of income, a degree of economic independence which they did not enjoy 20 years earlier, and access to other resources from governments (Altman \& Sanders 1995; Smith 2001b). In remote communities and outstations, welfare income has also supported Indigenous efforts to remain actively engaged in the customary economy on their own lands.

A major government initiative in the mid 1970s was the creation of the Community Development Employment Projects (CDEP) scheme to divert Indigenous people, initially those living in remote communities, away from entrenched reliance on welfare income and into community work projects. Under this scheme, Indigenous communities receive funding based on their welfare entitlements, with an additional payment toward capital costs in order to undertake community-based employment projects. Participants are expected to work part-time for their welfare entitlements (for a fuller discussion of the CDEP scheme see Morphy \& Sanders 2001). Income received for CDEP participation is in large part, funded by the Federal government. 6 Today one-quarter of the Indigenous working-age population in remote, rural and urban communities is engaged in working on CDEP schemes. While there is a continuing debate about whether CDEP activities should be defined as 'welfare work for the dole' or 'paid employment', participants are excluded from official unemployment statistics. This effectively takes them off the welfare rolls, and reduces the national Indigenous unemployment rate from 40 to 26 per cent (Butler 2001). The scheme has some staunch Indigenous advocates because it provides a modicum of local community control. However, a criticism of the scheme overall, and especially in 
rural and urban areas, is that it appears to have done little to generate sustained flows out of the 'comfort zone' of CDEP into unsubsidised paid employment in local labour markets and Indigenous enterprises.

It is not yet clear how the new welfare reform agenda-especially mutual obligation and requirements for active work participation-will be applied to Indigenous people. The McClure Report (2000b) paid inadequate attention to Indigenous welfare service delivery and policy issues. ${ }^{7}$ It did note research by Sanders (1999) indicating significant differences in the impact of breach rateswith Indigenous clients of Centrelink being 1.5 times more likely to incur an activity test breach and twice as likely to incur an administrative breach than non-Indigenous clients. Centrelink has subsequently decentralised some aspects of its welfare service delivery in remote regions, but the problem of high rates of breaching apparently remains.

More recently, the Federal government has also initiated a 'whole of government' trial in ten Indigenous communities to improve the way government departments interact with each other and with communities to deliver services and programs. ${ }^{8}$ But this pilot does not appear to include the Federal welfare payment system. In 2001 a central Australian community was assisted in developing a proposal for a gradual devolution to the Indigenous Community Council of greater authority over the administration of welfare services and income payments. The plan included proposals for targeted capacity building, community development, block funding, and a partnership with Federal government departments (Smith 2001a, 2002). This proposal was subsequently rejected by the relevant Federal departments. However a major 'income management' demonstration project, initiated by Indigenous leader Noel Pearson, has been significantly funded by the public and private sectors. It is currently being piloted with families at four Indigenous communities in Cape York Peninsula, north Queensland. This pilot project actively targets local service delivery, regional economic development, and the management of welfare and other income by families and communities. As yet, however, there is no publicly available overview or evaluation of the pilot upon which to assess the implementation process, the outcomes to date, or its potential for transferability.

In Australia, there is nothing comparable to the statutory framework in the USA which seeks to devolve responsibility for welfare services and administration to Native American communities and their governing bodies (see below). Nor is there, as yet, a cohesive welfare policy framework that stipulates how the national reform agenda will address the needs of Indigenous welfare recipients, how outcomes are to be monitored against benchmark objectives, or how the performance of government departments, Indigenous organisations and leaders involved in welfare reform initiatives will be assessed. In the absence of these, there may well be potential lessons - both negative and positive-to be learnt from examining the new statutory and policy framework that has been set in place in the USA. 


\section{The US social security system and the direction of reform}

While the universalist approach of the Australian welfare state has been described as 'radically redistributive' (Aaron 1992 cited in Whiteford 2000: 41; see also Atkinson, Rainwater \& Smeeding 1995), the American approach has been described as a patchwork of programs focusing on 'unabashed individualism, with the state taking a residualist approach in most welfare areas' (Kingfisher \& Goldsmith 2001: 717) and protecting 'only a minority of the population against only a few risks' (Richards 1994: vii-viii). Table 1 (above) lists the key distinctive features of the US and Australian systems. The American system draws on personal contributions via social insurance schemes. It provides employmentconditional benefits, including Earned Income Tax Credit (EITC), food stamps, and health care for some of the poor through the Medicaid program.

In comparison to Australia, the USA has a long tradition of State governments exercising significant discretion in some elements of welfare programs, including payment levels and administration (Kalisch 2000: 15). It has also moved further in devolving welfare service delivery and administration, in the name of more efficient and effective public administration. As a consequence, there has always been considerable variation in welfare benefit levels and eligibility criteria between the American States.

The drivers for welfare reform in the USA from the mid 1980s are broadly similar to those propelling the Australian reform process, including government concern with the dramatic increase in welfare caseloads and length of spells on welfare, the expanding welfare budget; and policy makers' concern about intergenerational transmission of welfare reliance, especially in single parent families (Bloom et al. 2002; Sawhill et al. 2002). While US Federal and State governments had begun welfare reform in the 1980s, the most significant changes took place in response to the introduction of two Federal laws: the Personal Responsibility and Work Opportunity Reconciliation Act (PRWORA) passed in 1996, and the Balanced Budget Act passed in 1997.

The welfare reform process in the USA has had a longer gestation and implementation timeframe than in Australia, and has been subject to detailed evaluation at national and State levels. In the USA, welfare reform is focused on providing temporary support for families with children and encouraging self sufficiency. The aims of the PRWORA are both economic and social. They include reducing welfare dependency, especially lengthy spells on welfare, reducing exnuptial births particularly among teenagers, encouraging the formation of twoparent families, and achieving greater work participation by welfare recipients, especially single mothers (Committee of Ways and Means 1996).

Under PRWORA, the US government's commitment to welfare as an entitlement ended. The emphasis on the temporary nature of safety net assistance was apparent in the new name for welfare-'Temporary Assistance for Needy Families' 
(TANF). Assistance is available to one and two-parent families with children under the age of 18 years, or students under the age of 19 years, who pass a means test. The US law has excluded illegal migrants and residents who have been in the country for less than five years from entitlement to welfare. It limits welfare spells to two years with a maximum lifetime entitlement of five years of assistance. Of a State's caseload, 20 per cent can be exempted from the five-year rule. A key aspect of the reform package is the use of more stringent sanctions (equivalent to Australian breaching) for not complying with work requirements and other welfare rules.

Under a complex statutory shifting of responsibility and accountability, the US government transferred significant additional responsibility for welfare provision to State governments and switched to a block TANF grant, handing over fixed sums to States to disburse as they wished (within some minimum regulatory guidelines). In order to qualify for the full Federal grant, a work participation rate of 25 per cent in 1997 rising to 50 per cent in 2001 was to be achieved in each State. The new law is particularly hard on teenage single mothers. It requires them to live with a responsible adult and attend school. They face a 25 per cent reduction in benefit if they do not help in establishing paternity. States receive funding for 'abstinence education' and a performance bonus if they reduce their ex-nuptial birth ratio (Committee of Ways and Means 1996: 7). In addition to TANF and food stamps, most States offer additional assistance for child care and transport costs. The law has been reviewed in 2002, and with policy proposals put forward by the President, further emphasises the promotion of conservative family values.

In conjunction with the tighter eligibility requirements outlined above, new 'Welfare to Work' (WtW) programs were established under the Balanced Budget Act 1997. The aim of these programs is to provide job opportunities and employment preparation and retention services for welfare recipients. The emphasis is on getting people into work rather than helping them to undertake additional training or education, which was a focus of the earlier Job Opportunities and Basic Skills Training (JOBS) program (Smith Nightingale et al. 2000). Further incentives to undertake paid employment are offered under an expansion of the EITC scheme.

These reforms have fundamentally reshaped the American safety net, certainly in a more radical fashion than any yet envisaged in Australia (Bloom \& Michalopoulos 2001; Sawhill et al. 2002). Between January 1993 and December 1999 the number of recipients fell from 14.1 million to 6.3 million, a drop of 56 per cent (and the number fell again to 5.8 million in June 2000) (Department of Health and Human Services (DHHS) 2000; Edelman 2002; Kilborn 2001). Welfare caseloads in general have fallen by at least 50 per cent in 29 States, and by at least 20 per cent in all States (Cornell et al. 2001). This dramatic decline in the number of people on the US welfare rolls following the welfare reforms of the mid 1990s is well known and is discussed in more detail below. 


\section{Welfare reform for Native Americans}

In the USA, the self-determination policy as articulated in the Indian SelfDetermination and Education Assistance Act 1975 and subsequent amendments and legislation, makes it possible for Indian Tribes to contract and compact with the Federal government to directly manage Federal programs. This process has expanded to include the devolution of welfare programs not only to State governments, but also to Tribal authorities. PRWORA amended the national Social Security Act (s. 412) to enable federally-recognised Indian Tribes, or consortia of such Tribes, to apply for TANF block Federal funding to directly design and operate their own welfare programs (Cornell et al. 2001; DHHS 2000; Hicks 2001).

Under the legislation, the Federal government redirects to the Tribe an amount equal to that which would have been provided to the State for welfare services to all Indian families residing in a proposed service area. The legislation also enables Tribes to enter into partnerships with State governments to contract them to provide support services to Native American families. In parallel with the TANF initiative, Federal funding was appropriated to the Native Employment Works (NEW) program to promote Tribal work activities and develop reservation employment opportunities.

Approval is based on the development and submission of a detailed Tribal TANF Plan, covering a 3 to 4 year period. It must identify its proposed service area and population, welfare policies and objectives, program guidelines and penalty regimes, and the welfare services to be provided, and present an economic development plan to support access to employment. Each Tribal TANF Plan goes through a Federal assessment process, and must obtain Federal government approval. Updated plans must be submitted every three years. To secure final approval, a Tribe has to have a governing body and capacity to administer the program, and a mandate from its constituents.

Native American people participating in TANF for at least two years are required to participate in work activities. According to reports to Congress, Tribes enjoy 'unprecedented flexibility' under this devolved approach. They have authority to use Federal welfare funds in any manner that is reasonably calculated to accomplish the overall welfare agenda. A Tribal governing body can deliver the program or outsource it, and determine policy, program and eligibility criteria in order to respond to local concerns and circumstances. ${ }^{9}$ It can decide what form of benefits are appropriate for its population based on locally relevant knowledge: for example, as assistance in the form of cash, payments, food vouchers, clothing, shelter, utilities, household goods, personal care items, child care, and transportation to work. It can decide what constitutes acceptable work: for example, it may include activities in the customary economy, job search, subsidised employment, community service, vocational training and education. And it can determine acceptable standards of work and participation requirements. Tribes may also define their own relevant concept of 'family' and 
'needy family' (which may take account of extended-family formations, and shared parenting arrangements). Tribal approaches to these matters must be laid out in their initial plan (DHHS 1999a, 1999b, 2000, 2002).

Implementation of a Tribal TANF is nevertheless subject to a statutory framework which stipulates planning, approval and funding processes. New national regulations were also passed in June 1999, stipulating conditions about the use of funds, program elements, and accountability, and specifying a cap on the amount of TANF funds that can be expended on administrative costs. Tribes are also subject to the same data collection and reporting requirements as State governments (DHHS 2000).

A number of Tribal groups have availed themselves of the opportunity, via TANF, to undertake responsibility for welfare. At the end of 2001, 34 tribal entities had taken over devolved responsibility for their own TANF programs. These include individual Tribal governments, as well as consortia of smaller Tribes seeking to achieve economies of scale through collaborative administration of a single TANF program. TANF programs now cover more than 170 Tribes in 15 States (out of 330 federally-recognised Tribes and 12 Alaskan Regional Associations designated as eligible to administer the Tribal TANF program if they so choose) (Brown et al. 2001; Cornell et al. 2001; Hicks \& Brown 2000).

The 34 Tribal programs assist a projected total of 17,000 Native American families per month out of a total of approximately 40,000 families; that is, at least onethird (probably more) of all Native American families (DHHS 2000). The number of families served monthly by individual Tribal programs ranges from eight to over 9,000. If all 38 pending plans are approved, it is estimated that Tribal TANFs will cover approximately half of all Native American families in the country. The existing Tribal TANF programs were expected to draw down more than \$86 million during the 2001 fiscal year (DHHS 2000). By the same year, a number of Tribal groups were also undertaking devolved responsibility for other related welfare functions. ${ }^{10}$ Tribal TANF is thus a unique hybrid program that seems to extract the benefits of both mainstream and specialised approaches to Indigenous service delivery. Identified ongoing problems, however, include the proportionately heavier financial burdens they bear in comparison to States, because Tribal funding is not equalised to account for the greater number of clients with multiple barriers to taking up employment, or for their historical lack of infrastructure (Cornell et al. 2001; Hicks 2001; National Congress of American Indians (NCAI) 1998, 1999).

\section{Key comparative characteristics: Native Americans and Indigenous Australians}

In order to explore possible lessons and relevant insights from this American welfare experiment, it is important to keep in mind the distinctive characteristics of the two indigenous populations, both relative to each other and in terms of the wider societies that encapsulate them. Native Americans and Indigenous 
Australians represent a small proportion of the population in each country and there are limited welfare data available for these groups. ${ }^{11}$

Of the total Australian Indigenous population of approximately 386,000 (in 1996), over 26 per cent live in either remote or very remote regions scattered across some 1,300 discrete communities, of which only 12 per cent have a population of 200 people or more. Almost two-thirds of the total Indigenous population live in reasonably accessible locations in rural regions and urban locations (compared to 94 per cent of the non-Indigenous Australian population who live in similar rural and urban locations (Commonwealth Grants Commission (CGC) 2001: 267). While participation in the customary economy remains evident in many remote discrete communities, a common feature of these and rural Indigenous communities is ongoing economic under-development and marginalisation characterised by weak labour markets, low levels of enterprise development and low levels of waged income.

The population census in each country is a key source of data. In the US Census, people are asked to identify the race to which they belong, including the options 'Native American' or 'Alaskan'. Until the most recent US Census in 2000, people were limited to one choice, but in the 2000 Census they could select more than one race. This wider choice makes comparisons with earlier census results very difficult. In the Australian censuses since 1971, respondents have been asked to identify themselves as 'Aboriginal' or 'Torres Strait Islander' and, since 1996, have been able to choose the option 'both'. This self-identification complicates any comparisons over time, because in both the USA and Australia people have been increasingly willing over time to acknowledge their indigenous origins (Gray 1997; Taylor \& Bell forthcoming). These issues are important for analysing any data relating to race, as not only has the propensity to identify changed over time, but also the emphasis on collecting accurate data has increased. This is true for administrative data as well as those collected by the central statistics office. For example, applicants for benefits and pensions in Australia have been given the option of voluntarily identifying as Indigenous Australians for over a decade, but people have not always completed the question, and answers have not always been recorded on departmental files.

Table 2 presents some summary statistics for Native American and Indigenous Australian families compared with the rest of the national population for 2000 (USA) and 2001 (Australia). In each case they represent a small share of the total population, at between 1 and 2 per cent. Compared with families in the population as a whole, a much higher proportion of Indigenous families-about one-third in each country-were not couple families. They were also more likely to be receiving welfare payments in the form of TANF or Tribal TANF in America, or Parenting Payment Single (PPS) in Australia. The Census definitions of 'family' and 'household' are different in Australia and the USA, so caution is needed in making cross-national comparisons (see Table 3 for a summary of the differences in definitions). 
Table 2. Selected characteristics of Native Americans (2000 Census) and Indigenous Australians (2001 Census)

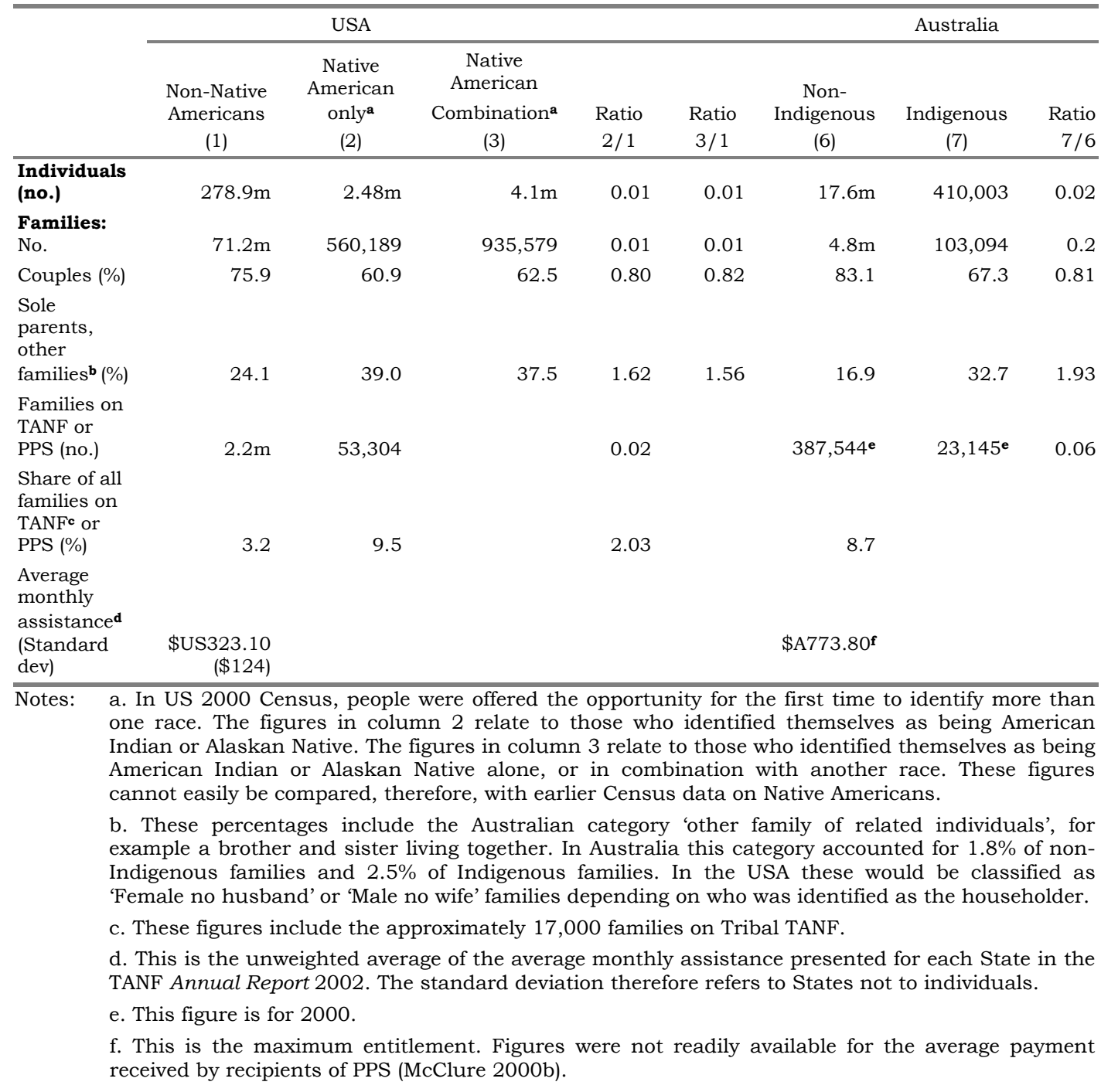

Sources: US Bureau of the Census, Census 2000; ABS Census 2001; DHHS 2002; DFACS Annual Report 2000-1.

The data from the 2001 Australian Census were only becoming available at the time of writing, so it has been necessary to rely on earlier comparisons based on the 1990-1991 Censuses for some key variables (the US Census is conducted only every ten years). These are presented in Table 4. Information about family dependence on welfare payments (then called Aid to Families with Dependent Children (AFDC) in the USA and Sole Parent Pension (SPP) in Australia) is also included, for comparison with the 2000-2001 figures. These results show that low relative levels of family and household incomes are common to both indigenous 
populations. The relatively high household incomes of Indigenous Australians can be explained by the large number of people living in a typical Indigenous household. In 1991, the median Indigenous household size was 4.0 compared with 2.9 for other Australians (Smith \& Daly 1996).

Table 3. Census definitions of households and families in the USA (1990) and Australia (1991)

\begin{tabular}{|c|c|c|}
\hline & USA & Australia \\
\hline Household & $\begin{array}{l}\text { All persons occupying a housing } \\
\text { unit in which the occupants live } \\
\text { and eat separately from others in } \\
\text { the building. }\end{array}$ & $\begin{array}{l}\text { A group of people who reside and eat } \\
\text { together in a single unit. They have } \\
\text { common housekeeping arrangements. }\end{array}$ \\
\hline Householder & Owner or renter of house. & $\begin{array}{l}\text { Head of house, whoever is listed first on } \\
\text { the census form. }\end{array}$ \\
\hline Family & $\begin{array}{l}\text { All persons in a household who are } \\
\text { related to the householder by } \\
\text { birth, marriage or adoption. A } \\
\text { household contains only one } \\
\text { family. }\end{array}$ & $\begin{array}{l}\text { Persons who are related by birth or } \\
\text { marriage. The nuclear family is taken as } \\
\text { the base structure and other families are } \\
\text { constructed around it. There can be up to } \\
\text { three families in a household. }\end{array}$ \\
\hline $\begin{array}{l}\text { Race of the } \\
\text { household or } \\
\text { family }\end{array}$ & $\begin{array}{l}\text { Depends on the race of the } \\
\text { householder. A Native American } \\
\text { household will be identified by the } \\
\text { presence of a Native American } \\
\text { householder. }\end{array}$ & $\begin{array}{l}\text { The presence of an Indigenous adult in a } \\
\text { household or family makes it an } \\
\text { Indigenous household or family. }\end{array}$ \\
\hline
\end{tabular}

The final rows of Table 4 highlight the relatively low levels of education of both Native Americans and Indigenous Australians. The difference is particularly pronounced for Indigenous compared with other Australians. The employment to population ratio for Indigenous Australians was also particularly low, at just over one-third of adults, compared with just under a half for Native Americans. The overall picture for Native Americans and Indigenous Australians in the 1990s is therefore one of ongoing socioeconomic disadvantage, with a relatively large proportion of families on welfare.

The discussion here of Indigenous welfare participation during the 1990s will focus on families on ADFC/TANF in America, and SPP/PPS in Australia, although this is just a partial picture of those receiving public assistance of various sorts. The question of interest is, what happened to participation in these programs over the 1990s given the reforms that took place? Data are available from the TANF annual reports for the USA and from DFACS for Australia. Fig. 1 presents data on the numbers receiving welfare support by race for the USA and for all Australians. Index numbers have been used to compare the groups because of the large differences in the absolute number of people involved. The three groups distinguished in America show a common pattern of rising numbers of ADFC recipients between 1990 and 1994 followed by a sharp decline. The number of Native American families receiving ADFC fell by 30 per cent. ${ }^{12}$ By 2000 there were 
Table 4. Selected characteristics of Native Americans (1990 Census) and Indigenous Australians (1991 Census)

\begin{tabular}{|c|c|c|c|c|c|c|}
\hline & \multicolumn{3}{|l|}{ USA } & \multicolumn{3}{|l|}{ Australia } \\
\hline & $\begin{array}{r}\text { Non-Native } \\
\text { American } \\
(1)\end{array}$ & $\begin{array}{r}\text { Native } \\
\text { American } \\
\text { (2) }\end{array}$ & $\begin{array}{r}\text { Ratio } \\
2 / 1\end{array}$ & $\begin{array}{r}\text { Non-Indigenous } \\
(4)\end{array}$ & $\begin{array}{r}\text { Indigenous } \\
(5)\end{array}$ & $\begin{array}{r}\text { Ratio } \\
5 / 4\end{array}$ \\
\hline Individuals (no.) & $246.8 \mathrm{~m}$ & $1.9 \mathrm{~m}$ & 0.01 & $16.6 \mathrm{~m}$ & 265,460 & 0.02 \\
\hline \multicolumn{7}{|l|}{ Families: } \\
\hline No. & $64.5 \mathrm{~m}$ & 449,281 & 0.01 & $4.2 \mathrm{~m}$ & 65,780 & 0.02 \\
\hline Married (\%) & 79.5 & 65.8 & 0.8 & 85.8 & 69.4 & 0.8 \\
\hline $\begin{array}{l}\text { Female no } \\
\text { husband (\%) }\end{array}$ & 16.0 & 26.2 & 1.6 & 10.2 & 24.0 & 2.4 \\
\hline Male no wife (\%) & 4.5 & 8.0 & 1.8 & 2.1 & 4.4 & 2.1 \\
\hline $\begin{array}{l}\text { Total not married }{ }^{\mathbf{a}} \\
(\%)\end{array}$ & 20.5 & 34.2 & 1.7 & 14.1 & 30.6 & 2.2 \\
\hline $\begin{array}{l}\text { Median family } \\
\text { income }^{\mathrm{b}}\end{array}$ & US\$35,225 & US\$21,619 & 0.61 & $A \$ 34,958$ & $\mathrm{~A} \$ 23,272$ & 0.67 \\
\hline $\begin{array}{l}\text { Median } \\
\text { household } \\
\text { income }^{\mathbf{b}}\end{array}$ & US\$30,056 & US\$19,900 & 0.66 & A $\$ 29,393$ & A $\$ 24,456$ & 0.83 \\
\hline $\begin{array}{l}\text { Families on AFDC } \\
\text { or SPPc (no.) }\end{array}$ & $4.0 \mathrm{~m}$ & 51,688 & 0.01 & 248,886 & 9,706 & 0.04 \\
\hline $\begin{array}{l}\text { Share of all } \\
\text { families on } \\
\text { AFDC or SPPc } \\
(\%)\end{array}$ & 6.2 & 11.5 & 1.9 & 6.0 & 15.0 & 2.5 \\
\hline Qualifications: & & & & & & \\
\hline $\begin{array}{l}\text { Intermediate } \\
\text { qualifications }^{\mathbf{d}} \\
(\%)\end{array}$ & 75.4 & 65.2 & 0.86 & 22.4 & 8.4 & 0.38 \\
\hline $\begin{array}{l}\text { Bachelor's } \\
\text { degreed (\%) }\end{array}$ & 18.5 & 8.1 & 0.44 & 8.7 & 0.9 & 0.10 \\
\hline $\begin{array}{l}\text { Employment/ } \\
\text { population } \\
\text { Ratio }\end{array}$ & 0.59 & 0.49 & 0.83 & 0.56 & 0.37 & 0.66 \\
\hline
\end{tabular}

Notes: a. These percentages include the Australian category 'other family of related individuals', for example a brother and sister living together. In Australia this category accounted for $1.8 \%$ of non-Indigenous families and $2.2 \%$ of Indigenous families. In the USA these would be classified as 'Female no husband' or 'Male no wife' families depending on who was identified as the householder.

b. See Table 3 for census definitions of household and family in the USA and Australia.

c. Includes families in the USA on Aid to Families with Dependent Children (AFDC) and those in Australia receiving the Sole Parent Pension (SPP).

d. In the USA the proportion relates to the population 18 years and over. In Australia it relates to those 15 years and over. The category 'intermediate qualifications' includes those who completed high school in the USA and in Australia, and those with post-secondary certificates including trade and other diplomas. For Australia the category 'bachelor's degree' includes those with higher degrees, graduate diplomas and bachelor's degrees.

e. Relates to the population 15 years and over.

Sources: US Census of Population 1990, Daly (1995), Daly and Smith (1996), DHHS (2000). 
an estimated 36,304 Native American families on welfare compared with 51,688 in 1990. Importantly, these figures do not include those on Tribal TANF which covered 4,480 families in February 2000. If the Tribal TANF figures are included, the reduction in the overall number of Native American families receiving welfare between 1990 and 2000 fell from 30 per cent to 21 per cent.

Fig. 1. ADFC/TANF and SPP/PPS recipients, USA and Australia, 1990-2000

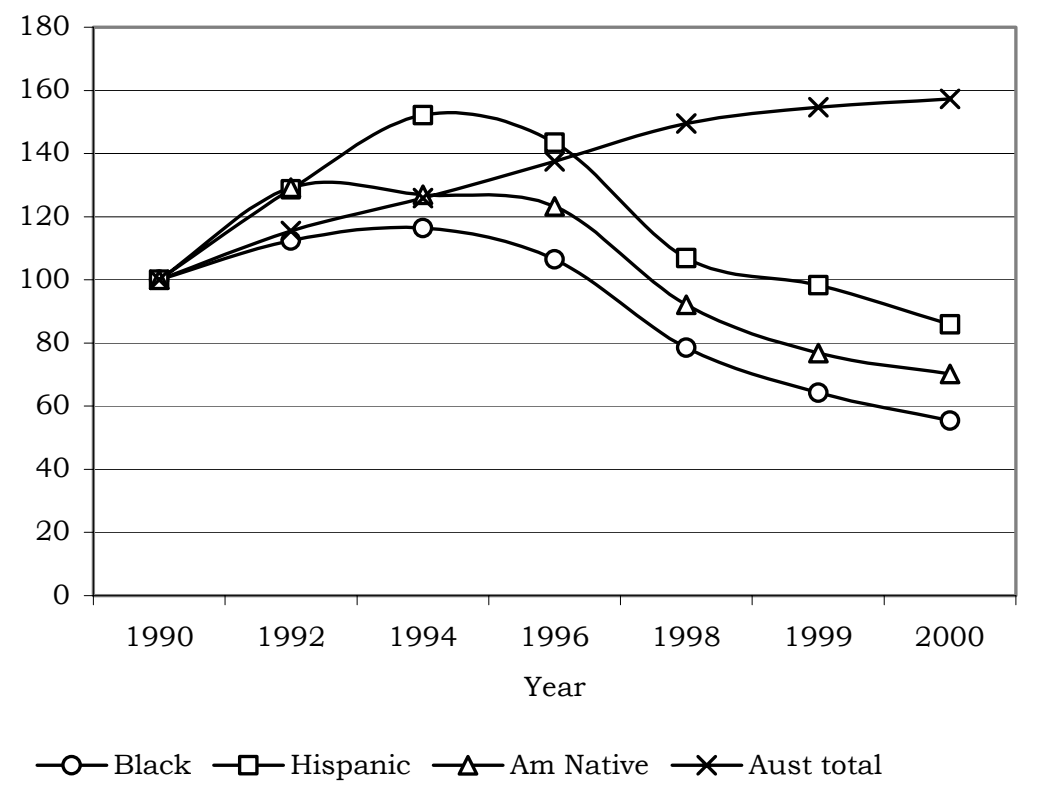

The results for Native Americans are in sharp contrast to the Australian picture. Over the period 1990-2000, the number of families receiving SPP/PPS in Australia increased by 57 per cent. Figures for Indigenous Australians are only available for selected years for special tabulations provided by DFACS and its predecessor, the Department of Social Security. These show that over the period 1992-99, the number of Indigenous people receiving SPP/PPS increased by 72 per cent. This large increase probably reflects rapid population growth and the added emphasis placed by DFACS on identifying Indigenous Australians in their records. It may also reflect the additional departmental effort that has been made to ensure that Indigenous Australians in remote locations are receiving their welfare entitlements.

Supporters of the US welfare reforms are quick to claim a major role for these reforms in explaining the decline in the number of welfare recipients. In line with this view, it could be argued that the Australian experience has differed so dramatically from that in the USA over the 1990s precisely because the welfare reform measures have not been so far-reaching. While it would be difficult to deny the importance of the reform measures themselves in reducing the size of welfare 
rolls, there are also other potentially important determinants of these changes. These include changes in the size of the eligible populations, in fertility rates, in the unemployment rate, and in the real value of benefits. Both the indigenous populations are relatively young and have higher fertility rates than the rest of the population (Daly 2001) and these factors would be expected to raise the number of families on income support well into the future.

Assessments of the US welfare reforms have attributed the decline in the numbers on welfare to the reforms themselves, the strong growth in the American economy until 2001, and the expansion of supporting programs such as the EITC and child-care programs (Sawhill et al. 2002). The apparent success of the American reforms in encouraging parents back into the workforce is likely to encourage Australian policy makers to look at the US experience as an example to be emulated. However, it is important to recognise the legislative, policy and indigenous cultural differences between the two countries, and the differences in how welfare reform is addressing indigenous circumstances in each. Furthermore the extensive body of American research evaluation of the overall impacts of the TANF reforms (including a smaller body of literature dealing with Tribal TANF) indicate there have been negative consequences for some groups of welfare recipients, and that a less than buoyant economy may currently be leading to less positive results. The US welfare experiment is therefore facing new challenges.

A number of potentially valuable lessons for Australia can nevertheless be extrapolated from the earlier implementation and outcomes (both positive and negative) of US welfare reform and TANF devolution. The object is not to suggest the straight importation of an American welfare model; but rather to derive useful policy insights and highlight pitfalls, for consideration in the design of a more effective policy framework for welfare reform for Indigenous Australians.

\section{Salutary lessons and potential future challenges for Australia}

\section{Work or education first?}

The hallmark of the TANF program, including Tribal TANF, is the policy of 'work first'. However, a significant barrier for American welfare recipients in general, in finding employment, has been their relatively low levels of educational attainment. In 1999-2000 about one-third of all adults receiving a welfare income had not completed high school (DHHS 2002). This raised the question of whether it was preferable to focus on education for this group, rather than employment, as a means of getting people off welfare. Numerous studies of this issue have been undertaken in the USA and most of the evidence supports an emphasis on getting welfare recipients into work first, rather than into education or training programs (see Gueron \& Hamilton 2002). One example is a comprehensive survey of the National Evaluation of Welfare-to-Work Strategies of 11 programs in seven sites by the Manpower Demonstration Research Corporation. It concludes that the evidence shows a greater impact on both employment and earnings from 
employment-focused programs than from education-focused programs (Bloom et al. 2002).

While 'work first' generally seems to produce the best overall results for welfare recipients, flexibility to choose vocational education or training for some individuals appears to be an important ingredient for program outcomes. In particular, the evidence for all American families who have multiple barriers to employment (for example, personal factors, lack of skills and education, difficulties with transport and child care) suggests that special strategies are required for this group. These include specialised screening and assistance with problems such as substance abuse and domestic violence, transitional employment programs including voluntary and community work, and intensive case management (Loprest 2002; Pavetti 2002). In other words, 'work first' works best in conjunction with tailored vocational training and other support.

For Native Americans, the evidence on the relative advantages of employment over educational programs seems to be less clear cut. In locations where Native American education levels and work experience are low, there appear to have been advantages in adopting an 'education first' strategy for identified individuals. Accordingly, many Tribal TANF programs have supplemented their 'work first' policy with education, training and supported-work and rehabilitation initiatives, and are adapting welfare program criteria to have these counted as active participation for the purposes of TANF work criteria (Brown 2001; Cornell 2000; Cornell et al. 2001; Hillabrant \& Rhoades 2001: 56). A number of Tribal TANF programs are also tagging the receipt of welfare assistance for young adults to their continued participation in schooling and, for other adults, to their undertaking health and rehabilitation programs.

In Australia, where the baseline Indigenous education levels are in fact lower than those of Native American Indians (see Table 4), a critical policy strategy will be to encourage greater participation and retention in schooling, at the same time as facilitating an active 'work first' approach where possible and relevant. This could be achieved by linking welfare payments for young Indigenous recipients (Youth Allowance) to attendance at school. But the US experience also suggests that more flexible welfare participation rules need to be established, under agreements with communities. It suggests as well that specialised one-to-one screening of individual welfare recipients is critical in order to determine the most effective balance of education, training and employment program support for each recipient.

'Work first' appears to have had dramatic positive impacts for a number of American welfare recipients, and this suggests that it may be a worthwhile policy objective in Indigenous communities that have viable local labour markets. It is an objective that would need to be targeted in conjunction with 'on-the-job' vocational training and education. However, a 'work first' objective will require significant additional effort by government, the private sector and Indigenous organisations to develop the economic strategies and paid employment opportunities that would have to be available in local communities. This objective 
will only be possible if an ongoing commitment of program resources and support are available at the local level, combined with block funding and coordinated program support from government.

\section{Economic development: the paramount issue for welfare reform?}

In fact the 'work or education first' debate simply masks a more fundamental issue. Perhaps the most important lesson to be learned from the US experiment with welfare reform for Native Americans is that economic development and employment growth are a critical part of any welfare strategy (Cornell 2002; Hicks 2002). In the USA this has been shown to be particularly important for Native American populations, with their strong residential and cultural ties to particular locations, often where employment opportunities are limited. A similar conclusion holds in Australia.

Recent evaluations of the situation in the USA (Antell et al. 2002; Cornell et al. 2001; DHHS 2000: 5, 6-9; Hicks 2002; Pandey \& Zhan 2000) reveal a critical underlying correlation. While the provision of education and training in job skills is an important strategy for Native American welfare recipients, it is a limited one; at best it is a holding position. A ten-year study of poverty, welfare reliance and economic development on one Indian reservation reported job opportunities had not increased at a rate that accommodated the rising number of educated Indians living there. Furthermore, approximately one in five Native American heads of households had at least four years of college, but still remained below the poverty line (Antell et al. 2002). On another reservation, long-term research indicated that many resident Indians had waged work experience and over 35 per cent of unemployed persons had technical and managerial employment experience and higher education degrees. Indeed, compared to all ethnic and minority groups on the welfare rolls in the USA, Native Americans are currently the best educated and have the highest participation rate in job preparation programs (Cornell et al. 2001: 6, 37).

In other words, a major obstacle to welfare exit for many Native Americans is not lack of education or job training, but lack of jobs per se in the areas where they live. Jobs are scarce on Indian reservations: the average unemployment rate across all Indian reservations in 1999 was 43 per cent; on some it was as high as 70-80 per cent (Brown 2001: 3; Hicks 2001). A recent study of a selection of Tribal TANF programs found that 64 per cent of Indian adults participate in some type of work activity. Of that total, only 11 per cent were working in unsubsidised employment, and only a small proportion of those were working full time. Approximately 33 per cent were undertaking job search and job readiness activities (DHHS 2000).

The Tribal TANF lesson is that without locally available jobs, education and training are of limited help to Native American welfare recipients (Cornell et al. 2001). Economic development and economic growth at the local level are the lynchpins for welfare reform and for securing better economic outcomes for 
individual recipients and their families (Cornell 2002; Cornell et al. 2001; Hicks \& Brown 2000: 7).

The economic reality is similar for Indigenous Australian communities, but with the additional factor that Indigenous Australians are starting from an even lower educational base than Native Americans. In many Indigenous communities there is a large and growing 'job gap' (that is, a difference between the size of community populations and the number of jobs available). According to Hunter and Taylor (2001) these 'employment deficits' are such that, given the projected Australian Indigenous population growth rate of twice the level of the rest of the population, there is a fundamental failure of job growth to keep up with growth in the working-age population. They conclude that the employment status of Indigenous Australians overall will in fact deteriorate, and this appears to be confirmed by early analysis of 2001 Census data. Furthermore, much of the work that people are moving into, especially in remote and rural communities, is essentially unpaid work experience or participation in the government-supported CDEP scheme. Perhaps the most critical issue for welfare reform for Indigenous Australians, as in America, is the fundamental failure to create jobs and sustainable economic development in the communities and regions in which indigenous people reside.

The Harvard Project on Indian Economic Development goes further. It reports that economic growth on American Indian reservations depends as much upon the ability of Tribes to reform their own governing institutions, in order to create an environment conducive to economic development and investment, as it does upon financial and program support from government (Cornell 2002; Cornell et al. 2001). In other words welfare reform is not only a problem of education and economic development, but also a problem of governance and jurisdictional devolution.

\section{The role of time limits}

The general lifetime limit for income support set by the USA Federal government under TANF is five years, with the States having the right to exempt up to 20 per cent of their caseload from this limit. There is considerable variation across States. At one end of the distribution, two States (Massachusetts and Michigan) have no lifetime limit, while three States (Arkansas, Connecticut and Idaho) have limits of 24 months or less (DHHS 2002). All States provide exemptions for particularly disadvantaged families and while adults may no longer receive TANF support after they reach their time limit, there is no time limit on support for child-only welfare cases. These account for about one-third of TANF recipients (Bloom et al. 2002; Grogger 2001). There is also a requirement that welfare recipients participate in work-related activities after two years on welfare.

The argument for imposing more stringent time limits (linked to mandatory work participation) in the welfare reform process was based on the perceived need to create an additional incentive for people to leave welfare and become selfsupporting. For this policy to be effective, people must have some choice about 
whether they stay on welfare or not, and the threat of being cut off must be credible, and not negative in its impacts on personal income levels. The evidence on the effects of time limits on individual behaviour is inconclusive, but their imposition seem to have created a perverse incentive for welfare administrators to keep individuals from enrolling in TANF in the first place, as well as to get people into work as quickly as possible. While some families have lost their entitlement to TANF support because they have reached their time limit, there also seems to have been considerable relaxation of time limits and exemptions for disadvantaged families in several States in recent years, especially in the context of the recent slowing of the US economy (Kilborn 2002; Moffitt 2002: 4).

The rules for Native Americans on Tribal TANF with respect to time limits have been more flexible from the beginning, in recognition of the limited employment opportunities on reservations and the multiple barriers to employment experienced by many recipients. The five-year lifetime limit is not applied in areas where the unemployment rate exceeds 50 per cent (NCAI 1999) although TANF recipients are required to participate in work-related activities after two years on benefits. These have been broadly defined and include job search training, child care, community service, education and training, and traditional subsistence activities (Brown et al. 2001). Migration off the reservations would have been the only alternative for many Native Americans if time limits had been strictly enforced, and this strategy, where applied, has had extremely limited success (Cornell et al. 2001; Pickering 2000). For all the same reasons, time limits are unlikely to have any positive impacts on welfare exits for Indigenous Australians.

\section{Sustaining the exit from welfare to work}

Recent US research examining the characteristics of people returning to welfare after leaving, reports that more than one-fifth of families that left welfare later returned, that nearly one in seven leavers are not working, and that those recipients with little education, limited work experience, no spouse or partner, and poor health are particularly at risk of needing welfare again (Brown et al. 2001; Greenberg 2001; Loprest 2002). Families that used transitional support services immediately after leaving welfare were less likely to return.

An important lesson from the US experience over the 1990s is that in order to reduce welfare rolls without creating extreme hardship for too many families, a combination of approaches is required. These include not only 'work first' conditions combined with education and training packages, but additional 'proemployment' program supports such as the EITC which reduce the size of the poverty trap, as well as support for child care and transportation (two of the factors frequently mentioned as barriers to employment in both the USA and Australia).

There is little equivalent data available on the rate of exits or returns to welfare among indigenous populations, be they American or Australian. It is known however, that both Native American and Indigenous Australian welfare recipients are characterised by substantial human capital deficits, health problems and a 
high proportion of sole-parent families. These factors cumulatively act as barriers to securing and retaining employment. Australian case study research suggests that recycling through multiple spells of employment and welfare support is an ever-present theme of Indigenous life cycles, and a 'significant determinant' of their low economic status (Henry \& Smith 2002; Smith 1991: 27-8, 1992: 78).

Furthermore, both Native American and Indigenous Australian households are involved in 'a complex combination of socially embedded economic activities outside wage work' (Pickering 2000: 149). Welfare has become a tightly integrated, essential component of the mixed economies of indigenous communities in both the USA and Australia (Cornell 2002: 1; Daly, Henry \& Smith 2002; Pickering 2000; Smith 2001b: 57). In order to cushion families from the potential economic difficulties that will probably flow from leaving welfare for low-paid work (even local work), and in order for recipients to then stay off the welfare rolls, they will need more than just jobs to go to. Recent US research reports that high flow rates on and off welfare suggest that many TANF leavers need more help immediately upon entering the workforce. Available help includes transitional benefits and access to services such as child care, health coverage, work expenses, transportation, and EITCs (Hicks 2002; Loprest 2002).

Similar job placement, post-employment mentoring, transitional benefits and support programs to promote job retention could be particularly important for Indigenous Australian long-term welfare recipients who commonly face multiple barriers to work. However, in Australia, many of these intensive assistance services and post-employment benefits are not easily accessible or available to Indigenous welfare recipients at the remote and rural communities in which they reside.

The recent establishment of Indigenous Employment Centres under the auspices of urban CDEP organisations, to provide job placement and mentoring support, is an attempt to address some of the transitional needs of Indigenous welfare recipients who have moved off welfare onto the CDEP scheme (Champion 2002). The American experience suggests it is worth considering extending the range and availability of post-employment transitional support services for Indigenous welfare recipients into remote and rural CDEP contexts, in tandem with job creation initiatives.

\section{The impact of welfare reform on families}

The issue of how American families in general have been doing under welfare reform is complex and has been hotly debated, not the least because the reforms commenced at the time of a strong economy but have also responded to a recent economic downturn. There are a number of variants in the outcomes. First, for those gaining employment, much of that employment is in low-wage jobs (more than half of those people have incomes below the US Federal government poverty line), and there is evidence of frequent job loss and limited upward employment mobility (Brown et al. 2001). Second, the great majority of welfare payments go to single mothers and they have exited the welfare rolls in large numbers. 
Employment rates among single mothers on welfare have increased dramatically since 1994 (from 60\% to 72\%) (Moffit 2002), and even higher levels of employment have been experienced by single mothers who have never married (a rise from $47 \%$ to $65 \%$ ). An important factor in this trend has been the expansion of EITC benefits and child-care subsidies.

This does not necessarily mean that such people have escaped poverty or are earning a living wage - a number appear to have exited welfare into low paid jobs with insecure tenure, and have restricted or no access to health benefits. While the income of single mothers as a whole has risen, some women leaving welfare are earning only slightly above what they were receiving on welfare. Furthermore, income from other household members has been found to be a key ingredient in sustaining the incomes of women leaving welfare (Moffit 2002). There is also evidence that families in the bottom fifth of the income distribution have actually experienced a decline in income since 1994, because their loss of welfare benefits has negatively offset any gains from earned income (Greenberg 2001; Sawhill 2001). Another aspect of the story for American families is that 'on any given day [in 2002] something like 40 per cent of former welfare recipients, or well over a million women, have no job' (Edelman 2002). These are often women who have left welfare because of sanctions for non-compliance.

A number of American researchers also believe that the massive decline in families on welfare was occasioned by those parents who were amongst the most 'job ready'. Parents who faced greater difficulties in securing employment owing to their multiple barriers were left behind. These families may well require a fundamentally different program approach, and a much longer timeframe for facilitating their transition into work (if it occurs at all).

Another recently noted 'side effect' of the welfare reform process is the emergence of the so-called 'no parent family' (Bernstein 2002) where a rising number of children are left with relatives (especially grandparents), friends or foster families in households without either their mother or their father. This constitutes a privatisation of welfare where, in order to stay in work, parents activate the social capital provided by their own extended family networks for the daily care of their children. In 2001, it was reported that the share of children living in such circumstances rose from 3.1 per cent in 1997 to 3.5 per cent in 1999 (an increase of 500,000 children). Among the suggested factors driving this 'family' formation are stresses on parents, loss of benefits, and the requirement to take on multiple low-wage jobs at irregular hours.

The outcomes for Native American Indian families under welfare reform is not as clear, primarily because there is little by way of published community-based or statistical data. A small body of research (e.g. Antell et al. 2002; Pandey \& Zhan 2000; Pickering 2000) suggests that the mainstream welfare reform agenda is quite explicit in its social and cultural engineering, emphasising the primacy of married two-parent families, legal marriage before childbirth, and the rearing of children solely by their parents. It is not clear whether Tribal TANF programs have sought to side-step this pressure, although a number of Tribal programs 
state they do define 'family' according to culturally-relevant values and structures. The ethnographic literature also suggests that Native American families place a similar emphasis upon shared parenting within extended families as do Indigenous Australians, and that some prefer to stay unemployed on reservations rather than leave to find employment (Antell et al. 2002; Pandey \& Zhan 2000; Pickering 2000). This is also the case in some Indigenous Australian communities.

In Australia, the impact of welfare reform on Indigenous families is entirely unclear. Moreover, the dearth of pilot studies and evaluation targeted to Indigenous welfare recipients under the reform process, and of published data about Indigenous welfare recipients at a national level, serves to further obscure trends and program outcomes.

\section{The policy focus: individuals, families, communities?}

Another potential lesson from the US welfare reforms is that, through the devolution process, the Tribal TANF programs 'are doing what most states have had considerable difficulty in doing: working intensely with multiple barrier families on reservations' (Hicks 2002: 5). A number of Tribal TANFs have steered policy away from a primarily individual-focused approach. Pickering's comments on the Lakota, echoed repeatedly in the small body of literature on Native American families and welfare recipients, are that: 'Fundamental to [their] culture [is] the importance of relatives, and the obligations of each individual to his or her family members is the most pervasive' (2000: 161), and that '[they] consider the characteristics and needs of the extended family in determining how to maximise the resources available to this larger group' (2000: 163). Using their legislative flexibility, many Tribal TANF programs have accordingly become 'proponents of addressing issues comprehensively with a whole systems approach, looking holistically at family needs' (Hicks 2002: 2). Welfare reform based on 'imagined' nuclear family formations, and on individuals as autonomous socioeconomic units, appears to have been rejected for Native Americans by Tribal TANF programs.

Australian ethnographic research similarly reports for Indigenous households that 'the extended family structure is the fundamental socioeconomic norm, and that each person operates within an intricate web of wider relations' (Henry \& Daly 2001; Smith 1991, 2000: 125). In Indigenous Australia, it is not simply individuals who are welfare dependent, but large extended families, their linked households and whole communities-and this dependence is inter-generational (Smith 2001b: 56). Similarly, in the USA, 'we are not simply talking about dependent individuals .... We are talking about dependent societies' (Cornell 2002: 2), and welfare dependence there is also inter-generational.

The great challenge for welfare reform for indigenous populations, in both countries, is not simply to reduce individual dependency or increase individual job skills, but to enhance the viability of community economies. Effective welfare policy and program reform for indigenous populations needs to adopt a whole of 
community' approach based upon the actual economic circumstances and capacities of individuals and their extended families, and on the realities of community economies.

\section{Welfare program coordination}

The Tribal TANF experiment highlighted, at an early stage, that it is critical to assess and match the needs of recipients to a package of resources and expertise provided by different agencies and programs (Hicks 2001; Hicks $\&$ Brown 2000). Long-standing problems in government coordination, and lack of horizontal program integration, can significantly impede sustained work-to-welfare transitions (Hillabrandt \& Rhoades 2001).

A particularly innovative mechanism developed to facilitate greater program and funding integration is the Indian Employment, Training and Related Services Demonstration Act 1992 (known as 'Public Law 477'). It allows Tribes to propose a plan for combining the funds they receive for a variety of employment, training, education and welfare services from Federal agencies (Brown 2001; Cornell 2002; Cornell et al. 2001; Hicks 2001: 5; Hillabrant \& Rhoades 2001: 30-31). These various program elements and related funds can then be delivered through a single plan, a single block grant budget and a single reporting system. An increasing number of Tribes have activated the ' 477 ' mechanism to assist in their delivery of TANF.

Public Law 477 provides an important integration mechanism for Tribal welfare reform, enabling:

- different programs to be geared more effectively to local Tribal circumstances;

- Tribal welfare providers to develop more coherent and 'whole of community' strategies for dealing with welfare needs;

- co-location of relevant services to provide welfare recipients with a one-stop shop, and to streamline eligibility processes and reporting burdens for different programs;

- a combined pool of funds to be created for welfare, employment and training activities;

- Tribal staff to be more easily deployed across TANF programs;

- reduction in the number of funding sources for which expenditure needs to be accounted; and

- more effective referrals and access of welfare recipients to programs and benefits.

Public Law 477 seems a particularly useful statutory mechanism that could be adapted for Australia where, currently, the lack of program integration and government coordination is pronounced. Given the demonstrated link for Native Americans between welfare exits and community economic development, the 
lack of such integration and coordination in Australia is an obstacle to effective welfare reform.

\section{Conclusion}

Policy diffusion and 'lesson learning' between the USA and Australia is already occurring with respect to broad welfare policy imperatives; if not with respect to the actual program mechanisms for achieving outcomes. ${ }^{13}$ The Australian Federal government, senior bureaucrats and researchers have tapped into the US and international policy trend towards 'welfare through work'. ${ }^{14}$ The USA has chosen statutory frameworks and devolution processes to activate reform; Australia has rested on a program mix of entitlement and program requirements, the application of which to Indigenous people has, as yet, not been clearly addressed.

Both countries have proceeded to impose 'workfare' or 'work-for-the-dole' conditions upon benefit receipt, in contexts where the level of benefits has also been reduced and where some minimum-wage jobs fail to provide a living wage. The more socially conservative intentions of American welfare policies which aim to reduce teenage out-of-wedlock pregnancies and increase married two-parent family formation, has not been taken up in Australia, although more moralistic program sanctions are being discussed in some government circles. ${ }^{15}$ Overall, in both countries, national welfare reform is increasingly emphasising targeted rather than universal coverage, and an individualist rather than collectivist approach to welfare (and an increasingly pathologised view of welfare recipients). However, the emphasis on individual rights and entitlements, to the detriment or neglect of family and community obligations and relationships, will be especially antithetical to Indigenous Australian social and economic systems of organisation.

An area of convergence in the welfare policy direction of the two countries is that of effectively denying people the option of remaining outside the labour force (Goodwin 2001). Such a system also tends to assign less value (for the purposes of conducting activity testing) to unpaid labour, particularly child-rearing, home duties, and work in customary Indigenous economies. In order to be sustainable, this policy objective requires an active and robust labour market; otherwise it simply re-badges welfare recipients, turning them into a class of working poor who have no recourse to welfare benefits, and who are unable to move into higher paid employment. The American TANF program is only now being tested in a weaker economy, and the recent data suggest that State caseloads may be increasing. Australian consideration of US welfare reform strategies will need to consider these more recent trends.

This paper has highlighted important similarities and differences between the indigenous populations of Australia and the USA, and their engagement in the national social security systems, which are under reform in both countries. Both Native Americans and Indigenous Australians are economically disadvantaged groups whose members are more likely to be dependent on income support than other members of their societies. For this reason they are particularly vulnerable 
to any adverse effects of welfare reform. The comparison suggests there are some important lessons, insights and challenges raised for welfare reform for Indigenous Australians:

- There is little doubt that for many American welfare recipients, the work first' focus of TANF has been effective. However it has been less successful for the hard-to-employ people with multiple barriers and for Native Americans residing in locations where jobs are not available. The Tribal TANF adaptation of a mixed package of 'work first' requirements in tandem with vocational training and education for those not immediately ready for employment is likely to be similarly effective in Australia.

- Education and work readiness are only effective where there are jobs available. The second lesson of the Tribal TANF reforms is that any Australian policy reform framework will need to have, at its core, a focus on the community economic development and job creation side of the welfare equation. A key issue for Indigenous Australian welfare recipients and for governments in the next decade will be how to create the jobs, in sufficient number and in community locations, to cope with the rapid growth in the Indigenous working-age population. To address that issue, welfare reform will need also to trial innovative economic strategies at the local and regional levels. To that end, government will need to make a greater upfront investment of resources and program support in the short and medium term in order to reap better employment and economic development outcomes in the future.

- Welfare-to-work should be treated as a continuum, not as a transition between two separate states. TANF has revealed that many welfare recipients, including Native Americans, require ongoing program and financial support for managed exits into employment if that transition is to be sustained over the long term. This necessarily includes the provision of locally available intensive case-management, and post-welfare support including ongoing mentoring, and child-care and transport services. Access to local support programs is particularly important in communities with a long history of welfare dependence.

- In populations with high unemployment rates resulting from weak local labour markets and low human capital endowments, time limits will have little positive effect. The American experience has been that exemptions and extensions increase in these circumstances. They need to be replaced by greater program attention to training, rehabilitation and the creation of locally available job opportunities.

- A wide range of activities including culturally-based work activities, participation in rehabilitation programs, family duties and child care, and attendance at school should be accepted as employment participation in Indigenous communities.

- Another critical lesson from Tribal TANF is that welfare is also a governance issue. In Australia this connection has not yet been made at the level of 
policy. In order to achieve the sustained community economic development that is necessary to create local jobs, Indigenous communities must have good governance and financial management capabilities. The American experiment of significant devolution via Tribal TANF has been supported by statutory, regulatory and policy frameworks, as well as funding, administrative support, and a program of governance capacity building.

- A focus on individuals will not be enough to reduce welfare rolls. As with Native Americans under welfare reform, the role of Indigenous extended family structures and their immediate communities should also be taken into account in the development of policy and programs. In particular, no matter the degree of cultural complexity or factionalism within communities, there are good grounds for arguing that, as in the USA, Indigenous welfare reform must be based on a 'whole of community' approach at the local level.

- Program fragmentation and lack of inter-departmental coordination have historically undermined economic development and welfare reform for Native Americans. This is also true for Indigenous Australians. Australia urgently needs an integrating mechanism similar to the US Public Law 477 to facilitate more effective 'bottom-up' planning and coordination, by Indigenous communities themselves, of welfare and labour market service delivery.

- While both the process and outcomes of the US reforms have been publicly evaluated in great detail at national and State levels, in both buoyant and weaker economic conditions, there is a comparative dearth of assessment of Tribal TANF's impact on the ground. Australia is probably even poorer in its evaluation record, although it does have more examples of qualitative community case study research than the USA. When reform initiatives and pilots for Indigenous Australians are developed, they must be carefully monitored and progressively reported on during implementation, and outcomes must be evaluated and publicly reported.

The American experience suggests that welfare reform initiatives may involve potentially increased per capita costs. But the evidence also suggests that greater short-term investment will probably offset the greater costs to the nation, and to Indigenous Australians themselves, of the high level of debilitating intergenerational dependence on welfare and the economic underdevelopment that currently prevail in Indigenous Australian communities.

\section{Notes}

1. The exception in Australia has been the existence, since the mid 1970s, of the Community Development Employment Projects (CDEP) scheme, which is discussed later.

2. The term devolution is defined to mean the transference of power and authority over jurisdictions from a higher, central level or order of government to other levels or forms of government. It may take the form of vertical transfers of power and authority 
over specific jurisdictions, or even over sub-components of specific jurisdictions (e.g. transferring authority over particular resources or functional areas). Such transferred power may be in respect to any possible combination of administrative, political, financial, functional and policy domains. Decentralisation, by contrast, is the delegation of responsibility to subordinate units of hierarchical jurisdiction which have primary accountability upwards to their superiors in the hierarchy (International Union for the Conservation of Nature (IUCN) 2001: 2). Decentralisation may provide more local administrative and management discretion, but financial control, policy independence and decision-making power are not necessarily transferred or more discretionary (Whiteford 2000: 112).

3. Australia's welfare expenditure is, nevertheless, a smaller proportion of GDP than in many OECD countries (Bloom et al. 2002; Goodwin 2001; Whiteford 2000: 87).

4. Changes include more women entering the workforce, and more men and women working part-time.

5. The McClure Report (2000b: 34) argued that 'Within the social support system .... social obligations are defined as mutual obligations, whereby the whole of the society has an obligation to provide assistance to those most in need. Similarly, those who receive assistance and opportunities through the social support system have a responsibility to themselves and the rest of society to seek to take advantage of such opportunities.'

6. It is possible for participants in the CDEP scheme to supplement their basic welfare entitlements with additional income generated through activity on the scheme, for example sale of arts and crafts. Altman, Gray and Sanders (2000) show that Indigenous people working on the CDEP scheme in 1994 had incomes 55\% higher than those of the Indigenous unemployed and 64\% higher than those not in the labour market.

7. See e.g. the Aboriginal and Torres Strait Islander Commission (ATSIC) submission (2000) to the McClure Reference Group on Welfare Reform.

8. This trial arose out of an agreement by the Council of Australian Governments in April 2002 to further actions that were recommended by the Council for Aboriginal Reconciliation to advance reconciliation and, in the case of this trial, to deliver more effective responses from governments to the needs of Indigenous Australians. The ten chosen communities are representative of all State and Territory jurisdictions.

9. For example, under s. 408 of the Social Security Act as amended by PRWORA, any month in which a native American TANF recipient spends time in Indian country where 50 per cent or more of all adults are not employed, does not count toward the applicable time limit for TANF assistance. There has been criticism that this cut-off point is too high, given that the majority of reservation populations have unemployment levels between 38 and 45 per cent.

10. In 2001, 257 Tribal child-care grantees serving more than 500 Tribes received $\$ 90$ million in Federal Childcare and Development Block Grants, 5 Tribes were operating their own Child Support Enforcement programs, and 78 Tribal grantees administered $\$ 15$ million in WtW grants to support employment opportunities under TANF (Brown et al. 2001: 2).

11. There appear to be more community-based research analyses available for Indigenous Australians concerning their engagement with the welfare system, than there are for Native Americans. 
12. The number of Black American families on welfare exhibited the sharpest decline to $55 \%$ of the 1990 level in 2000. The number of Hispanic families on welfare fell by $14 \%$.

13. We are not suggesting that full policy 'convergence' as defined and discussed by Seeliger (1996) is occurring: there is no obvious tendency for Australia and the USA to 'grow more alike, to develop similarities in structures, processes and performances'. Rather there appears to be convergence in particular policy objectives, albeit often through different policy instruments. In fact, the difference in mechanisms and statutory bases between the two countries may partly explain many differences in outcomes over time.

14. Kingfisher and Goldsmith (2001) note a similar process of policy diffusion and convergence between New Zealand welfare policy and instruments with those of the USA.

15. For example, suggestions have been made that ongoing receipt of benefits should be tied to mandatory participation by welfare recipients in parenting courses.

\section{References}

Aaron, H. 1992. 'The economics and politics of pensions: Evaluating the choices', in Organisation for Economic Cooperation and Development (OECD), Private Pensions and Public Policy, OECD, Paris.

Aboriginal and Torres Strait Islander Commission (ATSIC) 2000. Submission to the National Welfare Reform Reference Group, ATSIC, Canberra [available on the world wide web at www.atsic.gov.au].

Ah Kit, J. (MLA) 2002. 'Ministerial Statement', Maiden speech delivered as Minister assisting the Chief Minister on Indigenous Affairs, Northern Territory Government, Darwin, 7 March 2002.

Altman, J.C., Gray, M. and Sanders, W. 2000. 'Indigenous Australians working for welfare: What difference does it make?' Australian Economic Review, 33 (4): 355-62.

— and Hunter, B. 1998. 'Indigenous poverty', in R. Fincher and J. Nieuwenhuysen (eds), Australian Poverty: Then and Now, Melbourne University Press, Melbourne.

— and Sanders, W. 1995. 'From exclusion to dependence: Aborigines and the welfare state in Australia', in J. Dixon and R. Scheurell (eds), Social Welfare for Indigenous Populations, Routledge, London.

Antell, J., Blevins, A., Jensen, K. and Massey, G. 2002. 'Residential and household poverty of American Indians on the Wind River Indian Reservation', Joint Center for Poverty Research, Northwestern University and University of Chicago, 1 (8): 1-15.

Atkinson, A. Rainwater, L. and Smeeding, T. 1995. Income Distribution in OECD Countries, OECD, Paris.

Bernstein, N. 2002. 'Side effects of welfare law: The no-parent family', New York Times, 7 July 2002 . 
Bloom, D. Farrell, M., Fink, B. and Adams-Ciardullo, D. 2002. Welfare Time Limits: State Policies, Implementation and Effects on Families, Manpower Demonstration Research Corporation, New York [available on the world wide web at www.mdrc.org/Reports2002/welfaretimelimits/wtl_overview.htm].

- and Michalopouos, C. 2001. How Welfare and Work Policies Affect Employment and Income: A Synthesis of Research, Manpower Demonstration Research Corporation, New York.

Brown, E., Buder, K., DeWeaver, N., et al. 2001. 'Tribal sovereignty, devolution and welfare reform', W.K. Kellogg Foundation Technical Paper, Devolution Initiative, Michigan, Ill.

—, Cornell, S., Whitaker, L., Jorgensen, M., Springwater, M., Hale, M. and Nagle, A. 2001. Welfare, Work, and American Indians: The Impact of Welfare Reform, Report to the NCAI, Washington, DC.

Brown, J., Hirschfeld, R., and Smith, D.E. 1974. Aboriginals and Islanders in Brisbane, Commission of Inquiry into Poverty, AGPS, Canberra.

Brown, R. 2001. 'Welfare reform in Indian country: Current trends and future directions', Welfare Information Network (WIN) Issue Notes, June 2001 [available on the world wide web at www.welfareinfo.org].

Burtless, G. 2002. 'Can supply-side policies reduce unemployment? Lessons from North America', Australian Economic Review, 35 (1): 3-28.

Bush, G.W. (President) 2002. Working Towards Independence, Welfare reform policy statement by the US President, Washington, DC.

Butler, B. 2001. 'Welfare and social justice for Indigenous Australians', in F. Morphy and W. Sanders (eds), The Indigenous Welfare Economy and the CDEP Scheme, CAEPR Research Monograph No. 20, CAEPR, ANU, Canberra.

Champion, M. 2002. 'Urban CDEPs as Indigenous Employment Centres: Policy and community implications' CAEPR Discussion Paper No. 228, CAEPR, ANU, Canberra.

Coe, N., Acs, G., Lerman, R. and Watson, K. 1998. 'Does work pay? A summary of the work incentives under TANF', New Federalism: Issues and Options for States Series Paper No. A-28, The Urban Institute, Washington, DC.

Committee of Ways and Means, USA House of Representatives, 1996. Summary of Welfare Reforms, USA Government Printing Office, Washington, DC.

Commonwealth of Australia 2001. Australians Working Together: Helping People to Move Forward, A statement by Senator the Hon. A. Vanstone and T. Abbott MP, DFACS, Canberra.

Commonwealth Grants Commission (CGC) 2001. Report on Indigenous Funding, 2001, CGC, Canberra.

Cornell, S. 2000 “We gotta get somethin' goin’ around here!” Welfare reform, job creation, and American Indian economies', Paper prepared for the symposium Empowering American Indian Families: New Perspectives on Welfare Reform, Washington University, St Louis, Mo. 
2002. 'What is institutional capacity and how can it help American Indian Nations meet the welfare challenge?' Paper prepared for the symposium Capacity Building and Sustainability of Tribal Governments, Washington University, St Louis, Mo.

— Jorgensen, M., Brown, E., Whitaker, L., et al. 2001. Welfare, Work and American Indians: The Impact of Welfare Reform, Report to the NCAI by the Udall Center for Studies in Public Policy, University of Arizona, Tucson, Ariz, and the K.M. Buder Center for American Indian Studies, Washington University, St Louis, Mo.

Daly, A. 1995. Aboriginal and Torres Strait Islander People in the Australian Labour Market 1986 and 1991, ABS Occasional Paper, Cat.no. 6253.0, ABS, Canberra.

Daly, A. 1999. 'Prospects for Indigenous Australians in the welfare system', Agenda, 6 (1): $5-16$.

- 2001. 'Some lessons from welfare reform in the US for Australian welfare reform', Paper presented at the Economics Seminar Series, Research School of Social Sciences, ANU, 23 November 2001.

- Henry, R. and Smith, D.E. (in press) 2002. 'Some lessons for Indigenous welfare policy: Results of a longitudinal survey in an Indigenous community', Agenda, 9 (4).

— and Smith, D. 1996. 'The contemporary economic status of Indigenous Australian families', Australian Journal of Social Issues, 31 (4): 354-75.

Department of Family and Community Services (DFACS) 2000. 'Income support and related statistics: A 10 year compendium, 1989-1999', Occasional Paper No. 1, DFACS, Canberra.

- 2001. 'What Indigenous Australians and their communities need to know', Australians Working Together policy statement [available on the world wide web at http://www.together.gov.au/Groups/Indigenous/default.asp].

Department of Health and Human Services (DHHS) 1999a. Executive Summary: Final Rule Tribal Temporary Assistance for Needy Families Program and Native Employment Works Program, DHHS, Washington, DC [available on the world wide web at http:/ /www.act.dhhs.gov/programs/dts/execsum.htm].

— 1999b. Temporary Assistance to Needy Families (TANF) Program, Third Annual Report to Congress, DHHS, Washington, DC [available on the world wide web at http:/ / www.acf.dhhs.gov].

- 2000. Temporary Assistance for Needy Families (TANF) Program, Fourth Annual Report to Congress, DHHS, Washington, DC [available on the world wide web at www.hhs.gov/news/press/2000pres/20000218].

- 2002. Temporary Assistance for Needy Families (TANF) Program, 2001 Annual Report to Congress, DHHS, Washington, DC [available on the world wide web at http://www.acf.dhhs.gov].

Dolowitz, D. and Marsh, D. 2000. 'Learning from abroad: The role of policy transfer in contemporary policy-making', Governance, 13 (1): 5-24.

Edelman, P. 2002. The true purpose of welfare reform', New York Times, 29 May 2002. 
Ellwood, D. 2002. 'The US vision of work based reform: Promise, prospect and pitfalls', in T. Eardley and B. Bradbury (eds), Competing Visions: Proceedings of the National Social Policy Conference 2001, SPRC Report 1(2), SPRC, University of New South Wales, Sydney.

Goodwin, R. 2001. 'Work and welfare: Towards a post-productivist welfare regime', British Journal of Political Science, 31: 13-39.

Gray, A. 1997. 'The explosion of Aboriginality: Components of Indigenous population growth 1991-1996', CAEPR Discussion Paper No. 142, CAEPR, ANU, Canberra.

Gray, M. and Stanton, D. 2002. 'Lessons of the US welfare reform for Australian social policy', Unpublished paper presented to the 2002 Australian Conference of Economists, Adelaide.

Greenberg, M. 2001. 'Welfare reform and devolution: Looking back and forward', Brookings Review, 19 (3): 20-4.

Grogger, J. 2001. 'The effects of time limits and other policy changes on welfare use, work and income among female-headed families', National Bureau of Economic Research Working Paper No. 8153, National Bureau of Economic Research, Cambridge, Mass.

Guerin, J. and Hamilton, G. 2002. 'The Role of education in welfare reform', Welfare Reform and Beyond Brief No. 20, Brookings Institute, Washington, DC [available on the world wide web at www.brook.edu/es/research/projects/wrb/publications/pb/pb20].

Hamilton, G. 2002. Moving People from Welfare to Work, Manpower Demonstration Research Corporation, New York [available on the world wide web at www.mdrc.org/Reports2002/NEWWS_Synthesis/NEWWS_Synthesis.htm].

Henderson R.F. (Chair) 1975. Commission of Inquiry into Poverty: Poverty in Australia, First Main Report, AGPS, Canberra.

Henry, R. and Daly, A. 2001. 'Indigenous families and the welfare system: The Kuranda community case study, Stage two', CAEPR Discussion Paper No. 216, CAEPR, ANU, Canberra.

— and Smith, D.E. 2002. 'Three years on: Indigenous families and the welfare system, the Kuranda community case study', CAEPR Discussion Paper No. 229, CAEPR, ANU, Canberra.

Hicks, S. 2001. A Tribal Agenda for Welfare Reform Reauthorization, NCAI, Washington, DC.

2002. Testimony to the Senate Committee on Indian Affairs regarding implementation and reauthorization of the Personal Responsibility and Work Opportunity Reconciliation Act 1996, 10 May 2002, Washington, DC [available on the world wide web at http://www.ncai.org].

- and Brown, E. 2000. The Future of Welfare Reform: Considerations for Reauthorization, NCAI, Washington, DC.

Hillabrant, W. and Rhoades, M. 2001. 'The evaluation of the Tribal Welfare-to-Work Grants Program: Initial implementation findings', Paper prepared by Mathematica Policy Research Inc. for the DHHS, Washington, DC. 
Hunter, B.H. and Taylor, J. 2001. 'Indigenous jobs growth and unemployment, 1996-2006: The impact of CDEP', Australian Journal of Labour Economics, 4 (2): 65-76.

International Union for Conservation of Nature (IUCN) 2001. 'IUCN sustainable use policy dialogues- Governance: Equity and sustainable use of living natural resources in Southern Africa', IUCN Sustainable Use Specialist Group, web policy dialogue [available on the world wide web at www.iucn.org/themes/ssc/susg].

Kalisch, D. 2000. 'Social policy directions across the OECD region: Reflections on a decade of change', DFACS Policy Research Paper No. 4, DFACS, Canberra.

Keating, P. (Prime Minister) 1994. Working Nation, AGPS, Canberra.

Kilborn, P. 2001. 'Recession is stretching the limit on welfare benefits', New York Times, 9 December 2001.

Kingfisher, C. and Goldsmith, M. 2001. 'Reforming women in the United States and Aotearoa/New Zealand', American Anthropologist, 103 (3): 714-32.

Loprest, P. 2002. 'Who returns to welfare?' in Urban Institute, New Federalism: National Survey of American Families Series No. B-49, Urban Institute, Washington, DC.

McClure, P. 2000a. 'International developments in welfare reform', Appendix 6 in Interim Report of the Reference Group on Welfare Reform, DFACS, Canberra.

McClure, P. (Chair) 2000b. Participation Support for a More Equitable Society: Final Report of the Reference Group on Welfare Reform, DFACS, Canberra.

Moffitt, R. 'From welfare to work: What the evidence shows', Welfare Reform and Beyond, Brief No. 13, Brookings Institute, Washington, DC.

Morphy, F. and Sanders, W. (eds) 2001. The Indigenous Welfare Economy and the CDEP Scheme, CAEPR Research Monograph No. 20, CAEPR, ANU, Canberra.

National Congress of American Indians (NCAI) 1998. 'Addressing tribal employment responsibilities under welfare reform: A national forum, Green Bay Wisconsin 1998' [available on the world wide web at http://www.ncai.org/indian issues/WelfareReform.htm].

1999 'A comprehensive review of NCAI's efforts to address the impacts of welfare reform in Indian country', Paper presented to the Senate Committee on Indian Affairs briefing on welfare reform in Indian country, Washington DC [available on the world wide web at http://www.ncai.org/indian issues/WelfareReform.htm].

Pandey, S. and Zhan, M. 2000. 'How are families on reservations faring under welfare reform?' Working Paper No 2, Kathryn Buder Center for American Indian Studies, George Warren School of Social Work, Washington University, St Louis, Mo.

Pavetti, D. 2002. Helping the Hard to Employ, Urban Institute, Washington, DC.

Pearson, N. 2000. Our Right to Take Responsibility, Noel Pearson and Associates, Cairns, Qld.

Perry, J. 2002. 'One language, three accents: Welfare reform in the United States, and the United Kingdom and Australia', Family Matters, 56: 40-7.

Pickering, K. 2000. 'Alternative economic strategies in low-income rural communities: TANF, labor migration, and the case of the Pine Ridge Indian Reservation', Rural Sociology 65 (1): 148-67. 
Pierson, C. 2001. 'Learning from Labor? Welfare policy transfer between Australia and Britain', Graduate Program in Public Policy Discussion Paper No. 86, ANU, Canberra.

Richards, R. 1994. Closing the Door to Destitution: The Shaping of the Social Security of the United States and Aotearoa/New Zealand, Pennsylvania State University Press, University Park, Pa.

Ross, K. 2000. 'Recent trends in the demography of the indigenous populations of Australia, New Zealand, Canada and the United States of America', Unpublished paper, CAEPR, ANU, Canberra.

Sanders, W. 1999. Unemployment Payments, the Activity Test and Indigenous Australians: Understanding Breach Rates, CAEPR Research Monograph No. 15, CAEPR, ANU, Canberra.

Sawhill, I. 2001. 'From welfare to work: Making welfare a way station, not a way of life', Brookings Review, 19 (3): 4-7.

- Kent Weaver, R., Haskins, R. and Kane, A. 2002. Welfare Reform and Beyond: The Future of the Safety Net, Brookings Institute, Washington, DC.

Seeliger, R. 1996. 'Conceptualizing and researching policy convergence', Policy Studies Journal, 24 (2): 287-301.

Smith, D.E. 1991. 'Aboriginal unemployment statistics: Policy implications of the divergence between official and case study data', CAEPR Discussion Paper No. 13, CAEPR, ANU, Canberra.

- 1992. 'The cultural appropriateness of existing survey questions and concepts', in J.C. Altman (ed.), A National Survey of Indigenous Australians: Options and Implications, CAEPR Research Monograph No. 3, CAEPR, ANU, Canberra.

- ed. 2000. Indigenous Families and the Welfare System: Two Community Case Studies, CAEPR Research Monograph No. 17, CAEPR, ANU, Canberra.

— 2001a. 'Community Participation Agreements: A model from community-based research', CAEPR Discussion Paper No. 222, CAEPR, ANU, Canberra.

- 2001b. Welfare dependence, mutual obligation and the CDEP scheme: Lessons from community research and an overseas initiative', in F. Morphy and W. Sanders (eds), The Indigenous Welfare Economy and the CDEP Scheme, CAEPR Research Monograph No. 20, CAEPR, ANU, Canberra.

- 2002. 'Jurisdictional devolution: Towards an effective model for Indigenous community self-determination', CAEPR Discussion Paper No. 233, CAEPR, ANU, Canberra.

— and Daly, A. 1996. 'The economic status of Indigenous Australian households: A statistical and ethnographic analysis', CAEPR Discussion Paper No. 109, CAEPR, ANU, Canberra.

Smith Nightingale, D., Thompson, T., Pindus, N., Holcomb, P., Lee, E., Valente, J. and Trutko, J. 2000. 'Early implementation of the welfare-to-work grants program: Findings from exploratory site visits and review of program plans', Unpublished paper, Mathematica Policy Research Institute, Princeton, NJ. 
Taylor, J. and Bell, M (eds) forthcoming. Population Mobility and Indigenous Peoples in Australasia and North America.

Walker, R. and Wiseman, M. 2001. 'Britain's new deal and the next round of US welfare reform', Institute for Research on Poverty Discussion Paper No 1223, Institute for Research on Poverty, London.

Whiteford, P. 2000. 'The Australian system of social protection: An overview', DFACS Policy Research Paper No. 1, DFACS, Canberra. 


\section{Centre for Aboriginal Economic Policy Research Publications}

For information on earlier CAEPR Discussion Papers and Research Monographs please contact:

Publication Sale, Centre for Aboriginal Economic Policy Research, The Australian National University, Canberra, ACT, 0200, Telephone: 02-6125 8211, Facsimile: 02-6125 2789. Information on CAEPR, and abstracts or summaries of all CAEPR print publications and those published electronically, can be found at the following WWW address: http://online.anu.edu.au/caepr/

\section{MONOGRAPH SERIES}

7. Mabo and Native Title: Origins and Institutional Implications, W. Sanders (ed.), 1994.

8. The Housing Need of Indigenous Australians, 1991, R. Jones, 1994.

9. Indigenous Australians in the Economy: Abstracts of Research, 1993-94, L.M. Roach and H.J. Bek, 1995.

10. Native Title: Emerging Issues for Research, Policy and Practice, J. Finlayson and D.E. Smith (eds), 1995.

11. The 1994 National Aboriginal and Torres Strait Islander Survey: Findings and Future Prospects, J.C. Altman and J. Taylor (eds), 1996.

12. Fighting Over Country: Anthropological Perspectives, D.E. Smith and J.D. Finlayson (eds), 1997.

13. Connections in Native Title: Genealogies, Kinship and Groups, J.D. Finlayson, B. Rigsby and H.J. Bek (eds), 1999.

14. Land Rights at Risk? Evaluations of the Reeves Report, J.C. Altman, F. Morphy and T. Rowse (eds), 1999.

15. Unemployment Payments, the Activity Test and Indigenous Australians: Understanding Breach Rates, W. Sanders, 1999.

16. Why Only One in Three? The Complex Reasons for Low Indigenous School Retention, R.G. Schwab, 1999.

17. Indigenous Families and the Welfare System: Two Community Case Studies, D.E. Smith (ed.), 1999.

18. Ngukurr at the Millennium: A Baseline Profile for Social Impact Planning in South East Arnhem Land, J. Taylor, J. Bern and K.A. Senior, 2000.

19. Aboriginal Nutrition and the Nyirranggulung Health Strategy in Jawoyn Country, J. Taylor and N. Westbury, 2000.

20. The Indigenous Welfare Economy and the CDEP Scheme, F. Morphy and W. Sanders (eds), 2001.

21. Health Expenditure, Income and Health Status among Indigenous and Other Australians, M.C. Gray, B.H. Hunter and J. Taylor, 2002.

22. Making Sense of the Census: Observations of the 2001 Enumeration in Remote Aboriginal Australia, D.F. Martin, F. Morphy, W.G. Sanders and J. Taylor. 


\section{RECENT DISCUSSION PAPER SERIES}

221/2001 Indigenous land in Australia: A quantitative assessment of Indigenous landholdings in 2000, D.P. Pollack.

222/2001 Valuing native title: Aboriginal, statutory and policy discourses about compensation, D.E. Smith.

223/2001 Community Participation Agreements: A model from community-based research, D.E. Smith.

224/2001 A regional CDEP for four remote communities? Papunya, Ikuntji, Watiyawanu and Walungurru, W. Sanders.

225/2001 Building Indigenous learning communities, R.G. Schwab and D. Sutherland.

226/2001 Sustainable development options on Aboriginal land: The hybrid economy in the twenty-first century, J.C. Altman.

227/2002 The Indigenous population of Cape York Peninsula, 2001-2016, J. Taylor and M. Bell.

228/2002 Urban CDEPs as Indigenous Employment Centres: Policy and community implications, M. Champion.

229/2002 Three years on: Indigenous families and the welfare system, the Kuranda community case study, R. Henry and D.E. Smith.

230/2002 Towards an Indigenous order of Australian government: Rethinking selfdetermination as Indigenous affairs policy, W. Sanders.

$231 / 2002$ Population futures in the Australian desert, 2001-2016, J. Taylor.

232/2002

$233 / 2002$

$234 / 2002$

$235 / 2002$

$236 / 2002$

$237 / 2002$ Autonomy and the Community Development Employment Projects scheme, W.S. Arthur.

Jurisdictional devolution: Towards an effective model for Indigenous community self-determination, D.E. Smith.

Indigenous community stores in the 'frontier economy': Some competition and consumer issues, S. McDonnell and D.F. Martin.

Some competition and consumer issues in the Indigenous visual arts industry, J. C. Altman, B.H. Hunter, S. Ward and F. Wright.

Indigenous residential treatment programs for drug and alcohol problems: Current status and options for improvement, M. Brady.

Journey without end: Reconciliation between Australia's Indigenous and settler peoples, W. Sanders.

238/2002 Decentralisation, population mobility and the CDEP scheme in central Cape York Peninsula, B.R. Smith.

239/2002 Welfare and the domestic economy of Indigenous families: Policy implications from a longitudinal survey, A. Daly, R. Henry and D. Smith.

240/2002 Estimating the components of Indigenous population change, 1996-2001, Y. Kinfu and J. Taylor. 


\section{WORKING PAPER SERIES}

Available at no cost on WWW at http://online.anu.edu.au/caepr/

3/1999 Dealing with alcohol in Alice Springs: An assessment of policy options and recommendations for action, M. Brady and D.F. Martin.

4/1999 Aboriginal people in the Kakadu region: Social indicators for impact assessment, J. Taylor.

5/1999 Reforming the Northern Territory Land Rights Act's financial framework into a more logical and more workable model, J.C. Altman and D.P. Pollack.

6/2000 Governance and service delivery for remote Aboriginal communities in the Northern Territory: Challenges and opportunities, N. Westbury and W. Sanders.

7/2000 What's in it for Koories? Barwon Darling Alliance Credit Union and the delivery of financial and banking services in north-west New South Wales, N. Westbury.

8/2000 The relative social and economic status of Indigenous people in Bourke, Brewarrina and Walgett, K. Ross and J. Taylor.

9/2001 Indigenous communities and business: Three perspectives, 1998-2000, J.C. Altman.

10/2001 Indigenous Australian arrest rates: Economic and social factors underlying the incidence and number of arrests, B.H. Hunter.

11/2001 Sensitivity of Australian income distributions to choice of equivalence scale: Exploring some parameters of Indigenous incomes, B.H. Hunter, S. Kennedy, and D.E. Smith.

12/202 Indigenous Australians and competition and consumer issues: An interim review of the literature and an annotated bibliography, J.C. Altman, S. McDonnell, and S. Ward.

13/2002 The rise of the CDEP scheme and changing factors underlying Indigenous employment, B.H Hunter.

14/2002 Institutional factors underpinning Indigenous labour force participation: The role of the $C D E P$ scheme and education, B.H. Hunter.

15/2002 Generating finance for Indigenous development: Economic realities and innovative options, J.C. Altman.

16/2002 The spatial context of Indigenous service delivery, J. Taylor.

17/2002 The potential use of tax incentives for Indigenous businesses on Indigenous land, O. Stanley.

18/2002 Banking on Indigenous Communities: Issues, options, and Australian and international best practice, S. McDonnell and N. Westbury.

19/2002 One size fits all?: The effect of equivalence scales on Indigenous and other Australian poverty, B.H. Hunter, S. Kennedy and N. Biddle. 